\title{
"CORPOTERRITORIALIZAÇÃO" KATUKINA: LAMPEJOS ETNOGRÁFICOS SOB AS PERSPECTIVAS FEMININAS INDÍGENAS
}

\author{
Myrian Sá Leitão Barboza (D) \\ Universidade Federal do Oeste do Pará I Santarém - PA - Brasil
}

Larissa Duarte Ye'padiho Tukano (1) $₫$

Jaime Xamen Waiwai $\triangle$ 
Neste artigo, propomos o conceito de "corpoterritorialização", fundamentado nas perspectivas femininas indígenas, porque acreditamos que a territorialização se constitui como um processo corporal onde corpos e fluidos femininos contagiam, direcionam e regulam a coexistência indígena com e entre o território, e seus constituintes. Assim, argumentamos que as/os Katukina (território Rio Biá, Amazonas) constroem e reconstroem ativamente seus mundos sociais e físicos conceitualizados em termos de gênero e corporalidade, embora sejam influenciados por diferentes marcadores, incluindo espiritualidade, parentesco, mobilidade, dieta, entre outros. Baseado nos movimentos (cotidianos e sazonais) e nas cosmopoéticas de gênero Katukina, além da retomada do "território epistêmico" feminino indígena, demonstramos a importância feminina e a complementaridade na territorialização, timidamente retratada na academia.

Palavras-chave: corpoterritorialização, perspectiva indigena feminina; gênero;

\section{território; sentidos e sensações; Katukina do Rio Biả.}

\section{KATUKINA "BODY TERRITORIZATION": ETHNOGRAPHIC GLIMPSES INTO FEMININE INDIGENOUS PERSPECTIVES}

\section{ABSTRACT}

In this paper we propose the "body territorialization" concept, (corpoterritorialização, in Portuguese), based on indigenous feminine perspectives, because we believe that territorialization is a corporal process in which the feminine body and fluids infect, drive and regulate indigenous coexistence with and between territory and their constituents. Thus, we argue that the Katukina (Biá River Territory, Amazonas state, Brazil) actively build and rebuild their social and physical worlds, conceptualized often in terms of gender and corporeality, although they are influenced by different markers including spirituality, kinship, mobility, diet, among others. Based on Katukina gendered movements (daily and seasonal) and cosmopoetics, in addition to the resumption of indigenous feminine "epistemic territory", we demonstrate feminine importance and complementarity in the territorialization, timidly mentioned in academia.

Keywords: Body Territorialization,

feminine indigenous perspective; gender; territory; senses and sensations; Katukina from Biá River.

\section{“CUERPOTERRITORIALIZACIÓN" KATUKINA: DESTELLOS ETNOGRÁFICOS DESDE LAS PERSPECTIVAS FEMENINAS INDÍGENAS}

En este artículo proponemos el concepto de “cuerpoterritorialización”, basado en perspectivas feministas indígenas, porque creemos que la territorialización es un proceso corporal donde los cuerpos y fluidos femeninos contagian, dirigen y regulan la coexistencia indígena con el territorio y sus constituyentes. Por lo tanto, argumentamos que las/los Katukina (Territorio del Río Biá, Amazonas, Brasil), construyen y reconstruyen activamente sus mundos sociales y físicos conceptualizados en términos de género y corporeidad, aunque estén influenciados por diferentes dimensiones: espiritualidad, parentesco, movilidad y dieta, entre otros. Basándonos en los desplazamientos (diarios y estacionales) y “cosmopoéticas” Katukina de género, así como la reanudación del "territorio epistémico" femenino indígena, demostramos la importancia femenina en los procesos de territorialización, retratada tímidamente en la academia.

Palabras clave: Cuerpoterritorialización

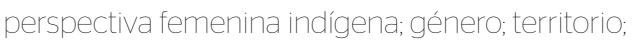
sentidos y sensaciones; Katukina del río Biá. 
"MEU CORPO É MEU LUGAR DE FALA"

(PRATES 2018:63)

$[\ldots]$

meu corpo

eu nomearia

território

se pudesse

inventar

um idioma próprio

$$
\begin{gathered}
\text { meu corpo é } \\
\text { meu lugar } \\
\text { de fala, }
\end{gathered}
$$

meu corpo é meu território:

[...]
"CARTOGRAFIA DO IMAGINÁRIO"

(GRAÚNA 1999:69)

...do meio da noite

ao meio do dia

o espanto do universo

retalhado em fatias

alimenta o poema

e a vertiginosa fome de vencer o intrincado mundo das palavras da noite ao meio dia

(a)talhos e fatias

dos muitos caminhos do mundo

alimentam

a cartografia do imaginário

do corpoema.
"IRIS DO ARCO-ÍRIS"

(M. ALVES 1998[2002]:30)

As meninas dos olhos

tornaram-se mulher

no caminho da cor do arco-íris

na mítica, mitologia real

$$
\text { ativa }
$$

vida

Os movimentos de corpos

reconstroem a fala

O movimento no corpo

axioma do silêncio

agente

a gente

há gente

Ah! Gente

Há

avanço na expressão

os corpos falam.

\section{INTRODUÇÃO: DE RELAMPEJOS POÉTICOS A LAMPEJOS ETNOGRÁFICOS}

Inicialmente e propositalmente, selecionamos versos femininos para o desabrochar do nosso artigo, porque estes corpoemas também relampejam e nos incitam a refletir sobre a atuação dos corpos femininos como territórios, e sua interação com os territórios. A poeta negra Lubi Prates retrata e reivindica, de maneira poética e poderosa, o corpo feminino como "território e lugar de fala" (Prates 2018:63). Na sequência, a poeta indígena e nordestina, Graça Graúna (1999), ilustra o efeito das palavras na formação de corpoemas inseridos em uma cartografia do imaginário; no arremate, a poeta negra Miriam Alves (1998[2002]) exclama e conclama que existem expressões nos movimentos silenciosos - ou melhor, silenciados - dos corpos femininos, no processo de passagem de meninas até se tornarem mulheres. Assim, de maneira inspiradora e potencializadora, três corpos femininos, indígenas e negros, eclodem e nos fortalecem na escrita do presente artigo. 
Estes corpoemas, escritos por mulheres brasileiras, também brindam a relevante discussão dos coletivos feministas latinos sobre corpo feminino e território, que vem tomando fôlego nos últimos anos (Cabnal 2010, 2012, 2015; Espinosa Miñoso 2014; Hernández 2016; Paredes 2011, 2017). Uma vertente destes coletivos é encabeçada por indígenas latinas, como Julieta Paredes, Lorena Cabnal e Lolita Chávez, as quais qualificam seus territórios como cuerpo-tierra ou territórios cuerpos-territórios (bodyland territories). As autoras argumentam que esta categoria carrega a noção de opressão e violência histórica da colonização europeia, primeiramente sobre o território-corpo e também sobre o território histórico, a Terra. A categoria "território corpoterritório" permite uma melhor compreensão da corporeidade, (inter)subjetividade e reflexividade feminina indígena, e reverbera o movimento de defesa de seus corpos e territórios que as autoras vêm postulando.

As intelectuais indígenas brasileiras Sandra Benites (2018) e Braulina Baniwa (2018) também discutem a importância e a singularidade dos seus corpos femininos nos processos de construção do território. Todavia e lamentavelmente, a academia praticamente não faz menção e reflexão sobre as publicações de intelectuais indígenas, principalmente das autoras mulheres, mesmo diante de um importante cenário de aumento significativo da produção acadêmica indígena (L. Alves 2019a, 2019b; Tupinambá 2017). L. Alves (2019a:83) e Celia Correa Xakriabá (2018) defendem a produção da epistemologia nativa nas universidades, em especial na antropologia, onde muitos/as indígenas vêm lutando "pela demarcação e retomada do território epistêmico", a fim de evitar o "epistemicídio", conforme já vem alertando a intelectual negra Sueli Carneiro (2005).

Assim, frente a esta problemática, considerando-se a literatura indígena e baseandose nas reflexões sobre a maneira como os diferentes corpos indígenas territorializam o mundo ${ }^{2}$, propomos neste artigo discutir as nuances de gênero presentes no processo de territorialização das/os Katukina do rio Biá (Amazonas, Brasil). Nosso argumento baseia-se na premissa de que

1 O termo epistemicídio foi cunhado por Boaventura de Sousa Santos (2007) para retratar o extermínio do conhecimento e das tradições dos povos originários frente à histórica exploração colonial.

2 Parte deste artigo constitui a tese de doutorado de Myrian Barboza (Barboza 2019), condecorada com o título de melhor tese do ano de 2019 do prêmio "Marianne Schmink Outstanding Dissertation Award", do programa Tropical Conservation and Development (TCD), do Center for Latin American Studies, da University of Florida. Parte deste artigo também foi apresentada no Simpósio Temático (ST-35): "Mulheres indígenas e suas co-existências: inscrições etnográficas da relação entre gênero e terra”, durante O III Congresso Internacional dos Povos Indígenas da América Latina (CIPIAL), em julho de 2019. Os questionamentos iniciais e as discussões realizadas junto às proponentes deste simpósio, Nicole Soares-Pinto e Sandra Benites, também contribuíram para elaboração do presente artigo. 
a construção do território Katukina incorpora fortemente nuances de gênero, corporalidade e os "fatores sensoriais de territorialização" (Deleuze \& Guattari 1987), e todos estes entrelaçados refletem na dinâmica de regulação de acesso e uso do território. Para além disso, partindo de perspectivas femininas indígenas (Baniwa 2018; Benites 2018), oferecemos a concepção do conceito de "corpoterritorialização", porque defendemos o pressuposto de que a territorialização indígena se constitui como um processo corporal onde corpos e fluidos femininos contagiam, direcionam e regulam a interação indígena com e entre o território, e seus constituintes. Assim, proporcionamos um exercício preliminar de reflexão sobre o conceito de "corpoterritorialização", a fim de que esta iniciativa seja debatida, melhorada e incorporada nos estudos antropológicos e feministas.

Nosso encontro e vivência etnográfica ${ }^{3}$ foram realizados em quatro das sete aldeias Katukina ${ }^{4}$, em 2016 e 2017, além de experiência prévia de Myrian Barboza com as/os ${ }^{5}$ Katukina de 2009 a 2011. Desenvolvemos metodologias participativas, além de uma abordagem inovadora que consistiu na inclusão de artistas e pesquisadoras/es indígenas de outras etnias e coautoras/es do presente artigo, Larissa Tukano e Jaime Waiwai. Denominamos esta experiência de "etnografia do compartilhamento" (Barboza 2019) porque durante nossa vivência etnográfica, nós, autoras/es, compartilhávamos nossas impressões, estranhamentos e encantamentos. Larissa e Jaime constantemente comparavam aspectos culturais das/dos Katukina com os de seu próprio povo, e Myrian Barboza com seu mundo não indígena. Nossas diferentes cosmovisões, experiências e indagações nos inspiraram em um debate contagiante sobre a alteridade e a escrita etnográfica experimental do presente artigo.

Ressaltamos as assimetrias presentes no processo de elaboração deste artigo, que inclui o planejamento da temática, a organização das observações do campo, o diálogo com a literatura, o desfecho dos argumentos e a linguagem utilizada. Mesmo que nossa vivência etnográfica tenha sido marcada pelo intenso compartilhamento coletivo

3 Optamos por vivência etnográfica em vez de pesquisa etnográfica, baseados no conceito de "escrivivência", de Conceição Evaristo (2007). Acreditamos que nossas vivências individuais, seja através da feminilidade, no caso de Larissa e Myrian, seja como indígenas, no caso de Larissa e Jaime, nos fazem evocar o coletivo narrativo e social das comunidades de onde viemos: Amazônia indígena e Nordeste brasileiro.

4 De 2016 a 2017, a vivência etnográfica foi concentrada em quatro aldeias, porém, desde 2009, Myrian visita todas as aldeias presentes no território Katukina.

5 Mesmo cientes do uso atual do artigo x em referência à teoria Queer (Rea et al. 2018), optamos por adotar as inflexões "as/os" em menções aos relatos Katukina em relação à sua percepção dos microterritórios e dos universos femininos e/ou masculinos. 
de nossas sensações individuais, considerando as dinâmicas de alteridades e identidades, o trabalho final de escrita do texto foi liderado pela autora não indígena, que, por isso, assume o papel de primeira autora. Ainda assim, houve releitura e rearranjo do texto pelas/os coautoras/es, contribuição de estimado valor para construção do conhecimento. Reconhecendo esta postura, assumimos os desafios e as armadilhas nos esforços de construção de metodologias coletivas que tentam integrar a pluralidade e a diversidade de saberes, e combater a hegemonia positivista do saber científico. No entanto, estes esforços nunca estão totalmente livres de reluzir o viés epistemológico, político e ideológico da primeira autoria. Salientamos também que realizamos nossa vivência etnográfica com as mulheres e homens Katukina, porém não foi nossa intenção acender aos "nós" das mulheres Katukina, apenas retratar e discutir as nossas percepções e interpretações destas (inter)convivências.

O indígena, filósofo e antropólogo João Paulo Lima Barreto reconhece sabiamente e alerta para o perigo das tentativas de enquadramento e imposição das categorias nativas às teorias antropológicas, verdadeiras "armadilhas conceituais" (Barreto 2013, 2018; Barreto \& Mendes dos Santos 2017). Inclusive, o próprio
João Paulo apresentou sua confusão inicial, e de muitos indígenas e pesquisadores não indígenas, na tradução das categorias tukano wai (peixes) e wai-mahsã (super-humanos). Em sua dissertação de mestrado (Barreto 2013) e em recente livro publicado (Barreto 2018), João Paulo rediscute estas categorias, traduzindo-as para uma linguagem científica, porém fundamentado nas elucubrações e orientações junto ao seu pai. De acordo com João Paulo, ele sentiu a necessidade de "minimamente, sistematizar os conhecimentos tukano, na medida em que as transcrições mitológicas e o que eu conhecia da produção indígena não davam conta de expressar as ideias indígenas e nem apresentavam um suporte teórico nativo" (Barreto \& Mendes dos Santos 2017:88).

Outros intelectuais indígenas Tukano, como Dagoberto Lima Azevedo (2016) e Gabriel Sodré Maia (2016), trilharam caminhos parecidos com os de João Paulo e João Rivelino Rezende Barreto (2012), cursando pós-graduação em antropologia da Universidade Federal do Amazonas (UFAM), e possibilitando a revelação de "novos equívocos criativos" (Azevedo 2016:106). Dessa forma, estes intelectuais nos presenteiam com respeitáveis e brilhantes exercícios de reflexividade indígena, que devem ser melhor apreciados, respeitados e disseminados nos debates acadêmicos, 
sobremaneira pela etnologia indígena ${ }^{6}$, que, de maneira paradoxal, parece não levar a cabo as reinvindicações indígenas de decolonização do pensamento. Cientes e conscientes destas problemáticas, tentamos aqui, neste estudo, experimentar o exercício inverso de ajustes dos conceitos teóricos antropológicos frente aos conceitos nativos, conforme reivindicam indígenas (L. Alves 2019a; Azevedo 2016; Barreto 2013; Maia 2016; Tupinambá 2017; Correa Xakriabá 2018) e antropólogos pós-modernistas (Fisher 2018; Marcus 1998).

Ressaltamos que poucos estudos antropológicos (Barboza 2019; Barboza et al. 2011; Deturche 2009, 2012; Deturche \& Hoffman 2016) foram realizados com as/os Katukina da Terra Indígena Rio Biá, sendo que Larissa Tukano consiste na primeira artista, Jaime Waiwai no primeiro arqueólogo e Myrian Barboza na primeira mulher do campo da antropologia e biologia a realizarem trabalhos artísticos e acadêmicos com este grupo (Barboza 2019).

As/Os Katukina do rio Biá, falantes da língua Katukina, com uma população em torno de 650 pessoas, habitam uma região de 1.185 .792 hectares, localizada entre os municípios de Foz de Jutaí e
Carauari, no estado do Amazonas. O parentesco Katukina é dravidiano, com preferências de casamento por primos cruzados por afinidade (Deturche 2009). O casal Katukina se constitui como unidade essencial da vida social e ritual Katukina, porém eles possuem fortes divisões de tarefas (Deturche 2009). Os homens Katukina são responsáveis por atividades de caça, mas a pesca pode ser realizada por grupos femininos, masculinos ou pela unidade familiar. A pesca com uso de veneno timbó é normalmente praticada por toda a aldeia. A coleta de recursos da floresta pode ser realizada por grupos de mulheres, grupos de homens ou unidades familiares. As atividades agrícolas têm divisões de gênero de acordo com cada etapa: a fase inicial de abertura da floresta é realizada pelos homens e, posteriormente, cada unidade familiar ficará responsável pela manutenção de sua parcela. No entanto, muitas vezes, as mulheres vão juntas para coletarem frutos. A produção de farinha de mandioca, atividade contemporânea, é realizada por unidades familiares. Para os preparativos dos rituais, as/ os Katukina têm notáveis divisões de tarefas por gênero, com proibições de uso e acesso de

6 Baseado na dissertação de João Paulo, o antropólogo Marcio Silva (2018:5) também sugere que a etnologia indígena pode se beneficiar com os novos debates propiciados pelos intelectuais indígenas.

7 Michael Fisher (2018) alega que as abordagens centradas nas correntes teóricas do perspectivismo e animismo precisam tratar das questões políticas e ambientais na Amazônia. Para ele, o uso de um vocabulário próprio e peculiar, produtores de "slogans" exacerbados, compromete a compreensão antropológica das sociedades indígenas. 
territórios para as mulheres Katukina. No entanto, também existem restrições nas quais o esposo e o recém-nascido devem acompanhar a mulher.

As aldeias Katukina possuem histórias distintas de ocupação, composição de grupos, padrão de assentamento, configuração das casas, localização (distância das cidades) e mobilidade (Barboza 2019). Vamos utilizar a divisão territorial adotada por Deturche (2009), que considerou a localização das aldeias como resultado de suas histórias políticodemográficas e de suas próprias seleções. Em agosto de 2017, nossa última visita, as/os Katukina estavam localizadas/os em sete aldeias, distribuídas ao longo da região do rio Biá: 1) baixo (aldeias Boca do Biá e Gato); 2) médio (aldeias Janela, Sororoca, Bacuri e Santa Cruz); e 3) alto (aldeia Terra Alta) (Figura 1). A partir de 2016, a aldeia Gato foi deslocada para uma área próxima ao médio rio Biá, porém, vamos considerá-la como pertencente à região do baixo Biá, em função de sua forte relação com a aldeia Boca do Biá e a região do baixo Biá.

Organizamos o presente artigo nas seguintes principais sessões: 1 )
“'Corpoterritorialização’' lampejos etnográficos sob as perspectivas femininas indígenas", onde descrevemos o conceito de corpoterritorializaçãoe nossas inspirações para esta concepção; 2) "Nuances de gênero incutidas na 'corpoterritorialização' Katukina: diferentes espacialidades, temporalidades e expressividades", na qual exemplificamos diferentes contextos (espacial e temporal) de corpoterritorialização que apresentam

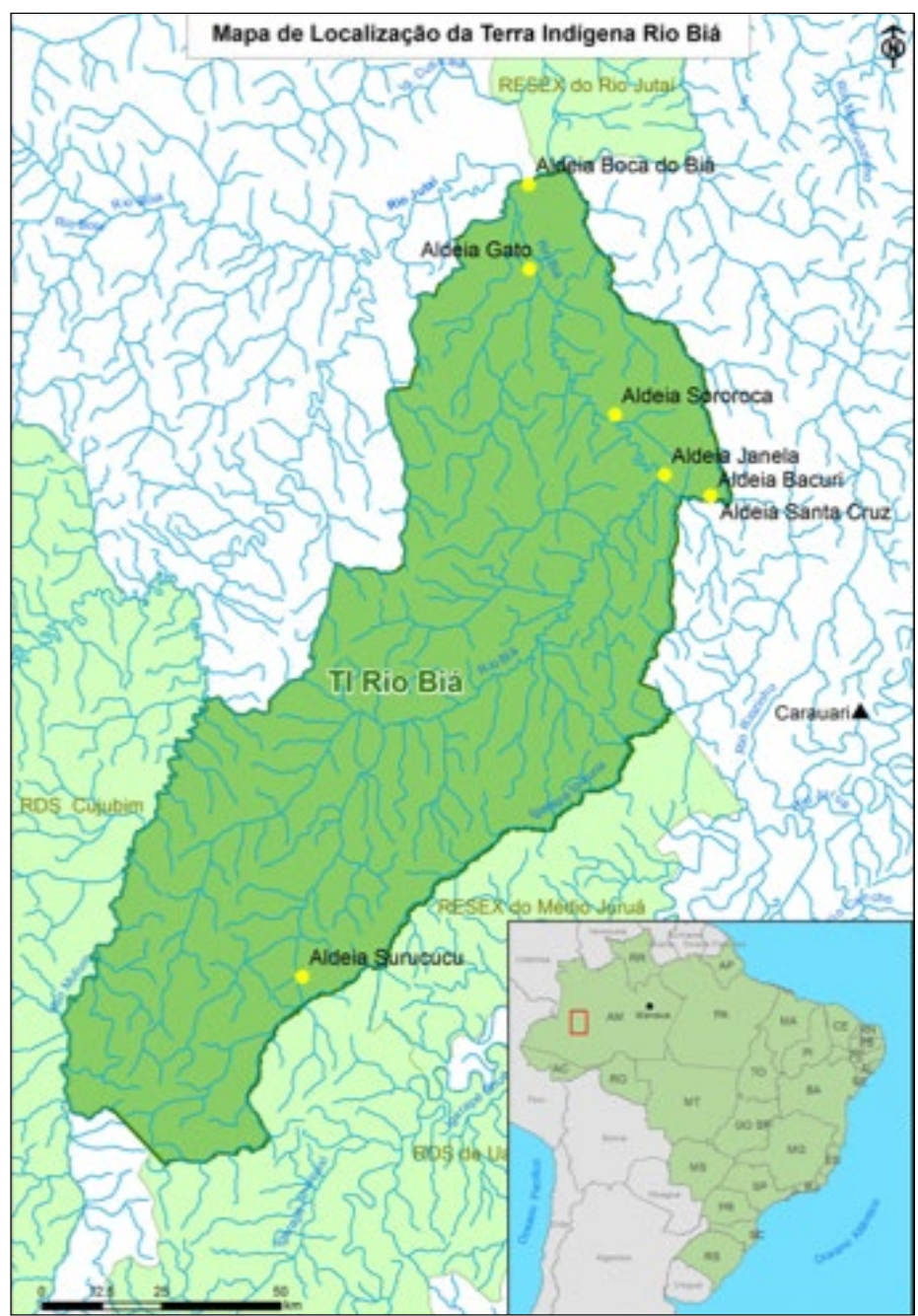

Figura 1 - Território Rio Biá (Amazonas, Brasil), com localização das aldeias Katukina, em 2011. Mapa: Rodrigo Marcelino (2015). 
nuances de gênero, e descrevemos os microterritórios masculinos, femininos e "antagônicos"; 3) "Assinaturas sensoriais da 'corpoterritorialização' Katukina”, onde apresentamos as medidas sensoriais (olfativas e fisicas) Katukina protetoras contra os seres intangíveis, além das assinaturas físicas da "corpoterritorialização" Katukina. Por fim, apresentamos as considerações finais do presente estudo.

\section{2. "CORPOTERRITORIALIZAÇÃO":}

\section{LAMPEJOS ETNOGRÁFICOS SOB AS}

\section{PERSPECTIVAS FEMININAS INDÍGENAS}

Durante nossa vivência etnográfica e várias conversas $^{8}$, refletíamos constantemente sobre a magnitude feminina indígena entrelaçada nas decisões que envolvem indivíduo, família e aldeia em questões de acesso, uso e construção do território. Apesar de grande parte dos estudos antropológicos sobre territórios indígenas não retratar a relevância das mulheres, como reivindica, de maneira assertiva, Braulina Baniwa (2018:167), constatamos que, entre as/os Katukina, as mulheres possuem um papel crucial na territorialização, em termos de escalas, espacialidades, temporalidades e diferentes expressividades, que iremos discutir na sessão seguinte.

Por muito tempo, a questão de gênero não foi significante nos estudos de etnologia das populações ameríndias da Amazônia, seguindo a tendência inversa das pesquisas etnológicas que ocorriam na Melanésia (Descola 2001). Este debate era continuamente evitado (Segato 1998), sendo que Cristiane Lasmar (1999:145, 148) associa este paradoxo à hegemonia da perspectiva masculina nas ciências sociais, à invisibilidade das mulheres indígenas e à estagnação teórica e etnográfica da etnologia sul-americana até a década de 80 . A partir deste período, há um aumento considerável na inserção da temática de gênero nos estudos antropológicos (Lasmar 1996, 1999; Maizza 2017), porém ainda existe pouca sensibilidade e grande resistência para reflexão e uso das epistemologias negras, indígenas e quilombolas (L. Alves 2019a; Correa Xakriabá 2018).

Recentemente, tivemos conhecimento do trabalho de Sandra Benites (2018), que nos inspirou fortemente na solidificação de nosso argumento e na concepção do conceito de "corpoterritorialização", um processo corporal de territorialização. Defendemos os pressupostos das antropólogas feministas (Belaunde 2001; Lasmar 2005; McCallum 2001) quanto à complementaridade das atividades de gênero e à atuação das mulheres indígenas como coparticipantes na produção de socialidades. Ademais, complementamos a imbricada relação entre gênero e território, e argumentamos que

8 Aqui, nos referimos às conversas entre nós, autoras/es. 
eles são mutualmente constituídos e socialmente construídos, e que as mulheres indígenas participam ativamente no processo de corpoterritorialização. A territorialização indígena é corporal porque estes territórios são elaborados e organizados a partir do complexo de conhecimento e ações atreladas aos corpos, por isso denominamo-la de corpoterritorialização, que ocorre principalmente conforme as singularidades dos corpos femininos. Nesta dinâmica, os fluidos dos corpos femininos, seja por meio do cheiro ou contato, contagiam corpos masculinos e infantis, e despertam atenção dos agentes externos. Dessa maneira, os corpos femininos se manifestam como elemento substancial da interação indígena com e entre o território, e seus constituintes. Nas próximas sessões, vamos exemplificar e descrever diversos casos de corpoterritorialização Katukina.

Sandra Benites (2018), liderança Guarani, professora e antropóloga, alega que a sabedoria das mulheres Guarani é baseada em seus corpos, o que afeta fortemente suas conexões com o território. Segundo Benites (2018:7-8), cada corpo de gênero é um lugar de conhecimento composto de diferenças, movimentos, lugares e demandas específicas:

$\mathrm{Na}$ realidade para falar de corpos é preciso falar das diferenças, dos movimentos e lugar onde possa caber esses corpos que muitas vezes vejo que os corpos não cabem por serem diferentes e por terem demandas diferentes. Os corpos falam, têm seus conhecimentos próprios que precisam ocupar seus espaços com suas diferenças (Benites 2018:7-8).

Benites (2018:70) esclarece que as mulheres Guarani consideram seus corpos e modo de ser como um elemento dentro do território da identidade. Da mesma forma, as mulheres Guarani constroem seu território com base nas especificidades de seus corpos. Assim, elas tentam conciliar corpos e territórios através de uma relação de cuidados e restrições - alimentação e movimento -, que dependem das conexões entre homens, mulheres, crianças e outros seres. Entre as/os Katukina e diversos grupos indígenas (Baniwa 2018; Belaunde 2006; Benites 2018; Krahô 2017; McCallum 1999), também encontramos um reportório complexo e cauteloso de normas que restringem o acesso, o uso e o movimento em relação a certos tipos de territórios e alimentos, estabelecidos principalmente conforme as condições femininas.

A categoria território corpo-território também enriquece o nosso debate com a proposição epistemológica de um feminismo comunitário elaborado por mulheres indígenas (Dorronsoro 2013). Este movimento valoriza e reivindica o direito indígena pelos territórios, enfocando a importância dos corpos femininos como espaço e ato político, conforme sugere a liderança maya-xinka Lorena 
Cabnal (2015). De forma similar, quando as intelectuais indígenas brasileiras (Baniwa 2018; Benites 2018; Correa Xakriabá, 2018) asseguram que seus corpos afetam a relação de reciprocidade com o território, esta filosofia abarca os sentidos, significados e comportamentos que verificamos entre as Katukina. Conforme assegura Célia Correa Xakriabá (2018), faz-se necessária a compreensão da conexão corpo-território indígena, inclusive na academia, como exercício de demarcação do território epistêmico:

A sociedade carece de recuperar valores da relação com o espaço corpo-território. Precisa considerar o território como um importante elemento que nos alimenta e constitui o nosso ser pessoa no mundo, não sendo possível nos ver apartados do território, pois somos também parte indissociável dele, nosso próprio corpo (Correa Xakriabá 2018:80).

A dinâmica de corpoterritorialização está intimamente relacionada aos seres intangíveis, agências não humana que possuem intencionalidade análoga à dos humanos (Viveiros de Castro 1998:471, 476), tendo em vista que as mulheres Katukina representam o principal desejo destes seres, conforme relatos das mulheres e homens Katukina. Mariano Katukina, por exemplo, informou que sua primeira esposa foi capturada na antiga aldeia Janela Velha por mapiri, um ser intangível que, na fase animal, aparece como sucuriju (Eunectes sp.). De acordo com Manel Katukina (aldeia Boca do Biá), nesta época, a aldeia Janela Velha estava repleta de mapiri, localizados em trilhas distantes, porém, mesmo assim, eles podiam sentir as/os Katukina e "varar" por um buraco dentro da terra, tipo um canal, desde o fundo da água. Este fato também foi destacado por Moka Lucia Katukina, da aldeia Gato.

Usualmente, as/os Katukina se referem aos seres intangíveis como agentes externos masculinos ${ }^{9}$ que, durante sua fase hominídea, almejam constituir famílias com as mulheres Katukina. Estes seres ocupam diferentes camadas do mundo (vento, buracos na terra, árvores, lagos, remansos, entre outros) e também podem ser proprietários de territórios ${ }^{10}$. Todavia, enquanto os Katukina são donos de territórios modificados por ação humana (casas, roças e capoeiras), os seres intangíveis são proprietários de territórios aparentemente "naturais", como barrancos, remansos, entre inúmeros outros (Barboza 2019).

Inúmeras vezes, as mulheres Katukina nos relatavam seu receio de serem capturadas pelos

9 As/Os Katukina relataram que existem dois seres intangíveis femininos, inclusive elas foram desenhadas. No entanto, as/os Katukina ilustraram principalmente seres intangíveis masculinos (Barboza 2019).

10 A condição de dono-maestria dos animais vem sendo intensamente discutida por Carlos Fausto (2008). Todavia, Barreto (2013) alerta que, no caso Tukano, são os lugares, em vez dos animais, que possuem donos. 
seres intangíveis. Em alguns casos, crianças ${ }^{11}$ podem ser levadas por eles, além de homens e cachorros, sendo estes últimos casos menos comuns (Barboza 2019). Aparte do temor de serem aprisionadas pelos seres intangíveis, as mulheres Katukina, e seus respectivos esposos, também possuem preocupação de serem levadas por homens não Katukina, como homens brancos e "índios brabos". Na oralidade Katukina, é muito recorrente a rememoração de um período ${ }^{12}$ cruel de chegada violenta, por meio de um barco batelão, de homens não indígenas junto com indígenas de outras etnias (Barboza 2019; Deturche 2009; 2012). Estes homens capturavam as/ os Katukina para trabalho escravo nas cidades, sendo que muitas mulheres Katukina eram violentadas ${ }^{13}$. As/Os Katukina narram, de maneira muito expressiva, um episódio de fuga de um casal Katukina para o rio Solimões, ocorrido nesta fase. A mulher Katukina estava grávida e, após o nascimento do bebê, o casal o deixou na floresta. Segundo Deturche (2009:28), esse bebê correspondia ao "esperma de homens brancos". Esta história é vividamente relembrada pelas/os Katukina de todas as aldeias, e reforça a elevada prudência sexual que as/os Katukina possuem pela maioria dos homens externos ${ }^{14}$.

No início de 2010, as/os Katukina informaram que um indígena "brabo" de outra etnia havia tentado sequestrar ${ }^{15}$ uma mulher Katukina da aldeia Janela enquanto ela estava na roça, resultando em fortes repercussões (Barboza 2019). Posteriormente, em fevereiro de 2010, uma

11 De acordo com Deturche (2009), adyaba i tyau seriam seres poderosos que devoram crianças.

12 Com base na descrição Katukina, supomos que elas/es se referem ao período do "boom da borracha" na Amazônia (1850-1920). Deturche (2009:31) acredita que o primeiro contato dos Katukina com não indígenas pode ter ocorrido nesta época ou um pouco mais cedo, baseado nas lembranças precisas dos Katukina em relação aos nomes dos envolvidos e os detalhes do episódio. Deturche (2009) alega que o limite da memória genealógica corresponde a duas gerações anteriores, ou seja, o tempo das/os avós/ôs ou bisavós/ôs Katukina interlocutoras/es equivale ao período um pouco anterior ao "boom da borracha".

13 Os relatos de naturalistas da época expõem os conflitos drásticos provocados pelo estabelecimento de seringais na Amazônia, através das expedições de correrias (Wolff 1998:11). Estes encontros resultaram em assassinatos em massa e/ou aprisionamento de indígenas, para posterior incorporação, especialmente de homens, no sistema seringal (Wolff 1998:168). As mulheres indígenas eram violentamente capturadas e vendidas após um estágio de "amansamento", um processo de "civilização" ou "domesticação". No entanto, não há registros escritos de capturas de escravos ou deslocamento forçado da população no rio Biá (Deturche 2009:31). Mesmo assim, o episódio do aprisionamento das/os Katukina é meticulosamente recordado pelas/os Katukina, representando um importante marcador temporal (Barboza 2019).

14 Vale ressaltar que as/os Katukina possuem interações históricas com indígenas da região, como Kambeba, Cocama, Miranha, Kanamari e Kulina, inclusive com ocorrência de matrimônios com Kambeba, Cocama e Miranha (Deturche 2009). Existem duas versões que explicam a chegada destes grupos: uma relaciona a presença de poucos homens Katukina; a segunda associa a fuga destes grupos em decorrência da ação de não indígenas ou indígenas hostis (Deturche \& Hoffman 2016:113).

15 Historicamente, o sequestro de mulheres indígenas por grupos rivais constituía-se como uma das principais causas de guerra entre os povos das terras baixas sul-americanas (Lévi-Strauss 1943). 
equipe da Fundação Nacional do Índio (FUNAI) realizou uma expedição ao Território Katukina para busca dos "índios brabos", que não foram encontrados (Almeida 2009). No caso dos homens Katukina, apesar de aparentemente e atualmente não "sequestrarem" mulheres Katukina, eles nos revelaram que Boneca Katukina, na época residia na aldeia Gato, teria sido raptada por João Surucucu Katukina, atual tuxaua (liderança) da aldeia Terra Alta, a aldeia mais distante de todo território Katukina. Tal episódio foi atribuído pelos homens Katukina como causa principal do conflito existente entre as aldeias Terra Alta e Gato.

Estes episódios históricos trágicos e as tentativas mais recentes de captura das mulheres Katukina - seja por agentes externos (brancos, "índios brabos" e seres intangíveis), seja pelos próprios Katukina, mesmo que raramente - podem auxiliar na tentativa de compreensão do pavor dos homens Katukina quanto à possibilidade de perda de suas esposas. Assim, mulheres e homens Katukina evitam violar as normas sociais, ponderando o risco de perda de membros da família, especialmente o rapto das mulheres pelos seres intangíveis.
Infelizmente, não conseguimos obter informações mais detalhadas da percepção das mulheres Katukina quanto ao significado delas constituírem famílias com os seres intangíveis, nem o que ocorre nos seus corpos e perspectivas diante destas experiências. De maneira geral, elas explicaram que, inicialmente, antes de serem raptadas, elas apresentam sintomas de enfermidade, um processo inicial de adoecimento ${ }^{16}$, e, após serem capturadas, passam a residir na casa dos seres intangíveis, não retornando ao “mundo" Katukina. Nestas casas, elas vão se tornar esposas dos seres intangíveis e poderão ter filhas/ os deles, constituindo, então, uma família junto ao ser intangível.

No caso das indígenas Djeoromitxi, Nicole Soares-Pinto (2017:72) explica que, nas tentativas de coleta e de uso de certas palmeiras durante suas regras (menstruação), as mulheres "podem ser capturadas para servirem de noras para os chefes das aldeiasárvores ${ }^{17}$, correspondentes ao espíritosDonos (Ibzia). Para Soares-Pinto $(2017)^{18}$, as/

16 Carlos Fausto (2008) e Costa (2007) discutem o processo de adoecimento causado pelas categorias indígenas dono e mestre. Segundo Fausto (2008), as relações assimétricas entre donos-mestres e populações ameríndias implicam funções de controle e cuidado, incorporadas a uma estrutura de singularidade-pluralidade.

17 As aldeias-árvores localizam-se nos ramos ou galhos de árvores de porte grande (samaúma, itaúba, cerejeira, mogno, apuí e castanheira) e palmeiras, e encontram-se articuladas entre si na mesma árvore ou em árvores diferentes (Soares-Pinto 2017:72).

18 Nicole Soares-Pinto (2017) integra o Laboratório de Antropologia da T/terra (UNB), criado em 2016, com a proposta de discutir as diferentes concepções e perspectivas das/sobre as T/terras, além de reunir pesquisadoras/es que atuam nas interfaces entre antropologia e direito (Lubel \& Soares-Pinto 2017). 
os Djeoromitxi encontram-se continuamente empenhadas/os na tentativa de não serem confiscadas/os pela perspectiva do Outro. Soares-Pinto (2017) alega que os modos de viver e habitar Djeoromitxi n/a "T/terra" e o sentido Djeoromitxi de território, é baseado na coexistência deles com os Outros (humanos e não humanos). A autora relaciona o movimento constante de expansão territorial Djeoromitxi (constituição de aldeias e reterritorialização) à conexão Djeoromitxi com o invisível. Assim, nas relações de coexistências com os espíritosDonos, os Djeoromitxi "garantem e mantêm (i.e. conservam) um lugar propriamente seu, ao coexistir com Outros (não humanos), os quais detêm, porque também constituem, um lugar" (Soares-Pinto 2017:70).

Desta maneira, impera entre vários grupos indígenas um esforço coletivo intenso de coexistência com os seres intangíveis, em uma relação permeada por cuidados e preceitos para impedimento de seu confisco. Nesta (inter)relação de coexistência, destacamos a posição e as atribuições das mulheres indígenas. Conforme já explicitado, as mulheres Katukina representam o principal alvo dos seres intangíveis, e seus corpos e fluidos são preponderantes nesta negociação de COMvivência e SOBREvivência.

\section{NUANCES DE GÊNERO INCUTIDAS NA “CORPOTERRITORIALIZAÇÃO" KATUKINA: DIFERENTES ESCALAS, ESPACIALIDADES, TEMPORALIDADES, INTERAÇÕES E EXPRESSIVIDADES}

Neste estudo, além das perspectivas femininas indígenas, vamos utilizar a compreensão de territorialização baseada em Deleuze \& Guattari (1987). Estes autores argumentam que os territórios existem quando as assinaturas de territorialidade são marcadas e quando a expressividade rítmica é fornecida. Segundo Deleuze \& Guattari (1987:315), os territórios existem quando há uma expressividade de ritmos, os "ritornelos". As matérias de expressão (qualidades), como por exemplo a cor dos pássaros ou dos peixes, "se tornam expressivas, ao contrário, quando adquirem uma constância temporal e um alcance espacial que fazem delas uma marca territorial, ou melhor dizendo, territorializante: uma assinatura". Dessa maneira, quando esse ritmo se torna expressivo, temporal e espacial, provoca uma assinatura territorial, ou seja, o processo de territorialização.

Entre as/os Katukina, verificamos que suas assinaturas territoriais são continuamente expressas através das nuances de gênero. Tanto os homens como as mulheres Katukina - através da complementaridade dos distintos papéis modelam, constroem e reconstroem o seu território. 
As/Os Katukina elaboram o entendimento de seu território por meio de diferentes espacialidades (micro e macroterritórios; territórios próximos e distantes), temporalidades (atividades diárias e sazonais) e interações (casal Katukina, família e aldeias; outros grupos indígenas, grupos não indígenas; e seres intangíveis).

Primeiramente, as ações de gênero Katukina afetam o acesso e o uso do território em diferentes unidades espaciais e distâncias (em relação às aldeias Katukina onde cada grupo vive): níveis micro e macro, que incluem árvores específicas, unidades domésticas (casas), aldeias, trilhas, barrancos, praias, rios, florestas e outros. Os homens Katukina possuem microterritórios especiais, ihkira horo e hokanin (Figuras 3 e 4, mais adiante), de acesso proibido às mulheres Katukina durante os rituais. O ihkira horo, buritizal (concentração de Mauritia flexuosa), consiste no local onde os homens coletam plantas para posterior elaboração de suas roupas ritualísticas no espaço hokanin, localizado na aldeia, onde eles também realizam brincadeiras e conversas antes e durante os rituais.

No entanto, as mulheres Katukina são capazes de restringir o acesso da família inteira a territórios considerados perigosos. Por exemplo, durante os primeiros dias do puerpério feminino, toda a família Katukina deve permanecer em casa. Além das atividades expressamente diferenciadas por gênero, realizadas na aldeia, existe uma gama de atividades desenvolvida fora da aldeia conforme o gênero. Os homens Katukina vão pescar e caçar em territórios afastados, enquanto as mulheres Katukina garantem e promovem o uso de territórios mais longínquos e historicamente relevantes para aldeias inteiras e também entre diferentes aldeias.

Em segundo lugar, os movimentos de gênero Katukina ocorrem em diferentes escalas de temporalidade, como atividades diárias e sazonais. Como mencionamos no parágrafo anterior, os homens Katukina realizam viagens masculinas com duração de vários dias, enquanto as mulheres Katukina estimulam a realização de viagens, junto com suas famílias, para territórios longínquos e relevantes historicamente, que podem durar inúmeras semanas ou meses.

Em terceiro lugar, as ações de gênero Katukina possuem múltiplos impactos, seja em nível familiar, com a aldeia e/ou com agentes externos distintos (outros grupos indígenas, não indígenas e seres intangíveis). Os homens Katukina levam famílias inteiras e membros da aldeia para venderem seus produtos nas cidades urbanas mais próximas (Foz de Jutaí ou Carauari), em negociações comerciais realizadas com agentes externos - patrões, comerciantes e outros. Como mencionamos anteriormente, durante o puerpério, as mulheres Katukina restringem o movimento familiar à casa, justamente para evitar que toda 
a família seja descoberta pelos seres intangíveis masculinos. Todavia, elas são capazes de encorajar e supervisionar a ida de famílias inteiras e aldeias para longas viagens a lugares distantes e históricos. De acordo com as Katukina, estas viagens são realizadas para obtenção de recursos especiais, como argila com coloração especial e fibras vegetais, ambos designados para atividades femininas de preparo de artefatos (vasilhas de barro e redes), que serão utilizados no dia a dia e nos rituais.

Embora unidades familiares inteiras viajem juntas e, em alguns casos, até mesmo a aldeia inteira, as principais intencionalidades da viagem estão relacionadas aos desejos femininos. Essas áreas constituem importantes territórios, intensamente utilizados no passado, especialmente entre as famílias Katukina do médio rio Biá. Essas viagens também representam uma maneira de tornar visível o uso de territórios longínquos para as outras aldeias Katukina, uma "assinatura territorial".

Dessa forma, as/os Katukina estão continuamente criando seus territórios através de interações que envolvem diferentes gêneros, gerações e seres. Para além disso, as mulheres Katukina comandam arranjos sociopolíticos das aldeias através da tomada de decisão das alianças matrimoniais entre as/os jovens Katukina. As mães Katukina são responsáveis pela escolha e negociação do casamento de suas filhas e filhos, o que impacta fortemente no futuro sociopolítico das aldeias.

\section{1. "SE FORMOS LÁ, VAMOS PERDER NOSSOS CABELOS": RESTRIÇÃO DO ACESSO FEMININO AOS MICROTERRITÓRIOS MASCULINOS}

Como as/os Katukina consideram diferentes unidades espaciais suscetíveis de posse e uso, adotamos o conceito de microterritórios para nos referirmos às menores porções do território Katukina. Sugawara (1988) refere-se ao microterritório como uma estrutura de múltiplas camadas, em vez de um espaço uniforme, e aplicou o termo microterritório em seus estudos sobre interações entre caçadores-coletores na África (Central Kalahari San). Descola (1996:46, 64) aplicou o termo microrregião entre os povos indígenas Achuar (alto Amazonas, Equador), em referência a seus assentamentos e limites territoriais que são definidos conforme elementos sazonais e hídricos.

Entre as/os Katukina, notamos microterritórios restritivos relacionados à mobilidade das mulheres Katukina durante os períodos ritualísticos. Durante os preparativos das festas, as mulheres são proibidas de ir ao microterritório ihkira horo (buritizal), onde os homens recolhem plantas para confecção de suas roupas, e ao microterritório hokanin, onde eles preparam suas roupas especiais. Geralmente, os homens Katukina usam o buriti 
(Mauritia flexuosa) para elaborar ihkira nook, vestimenta da maioria dos rituais (Figura 2A). No entanto, para o ritual Kohana, o maior e mais importante ritual Katukina, eles usam casca de árvore (envira) de uma planta, não identificada, para elaboração do koro (roupa) (Figura 2B).

Nós, autoras mulheres, Larissa e Myrian, não pudemos visitar o ihkira horo, localizado distante da aldeia. No entanto, Jaime realizou visita junto aos homens Katukina. Jaime revela que o ihkira horo está localizado bem distante da aldeia. Ao chegarem no local, os homens se espalharam e depois retornaram, mas logo permaneceram em silêncio por cerca de dez minutos. Eles estavam solicitando autorização aos donos dos buritis para realização dos cortes. Em seguida, realizaram os cortes, fizeram o preparo das vestimentas, o uso de rapé e aguardaram o início da noite para retornarem à aldeia.

Perguntamos às mulheres Katukina o que poderia acontecer se elas desobedecessem às normas sociais e visitassem estes locais (ihkira horo). Elas responderam, com gargalhadas, que poderiam perder seus cabelos e que não se arriscariam de forma alguma. Solicitamos mais informações, mas elas apenas riram e não forneceram explicações mais detalhadas para estes questionamentos.

A perda de cabelo é algo que deve ser evitado entre as Katukina. Apenas os homens, as idosas, as meninas e as mulheres que possuíam
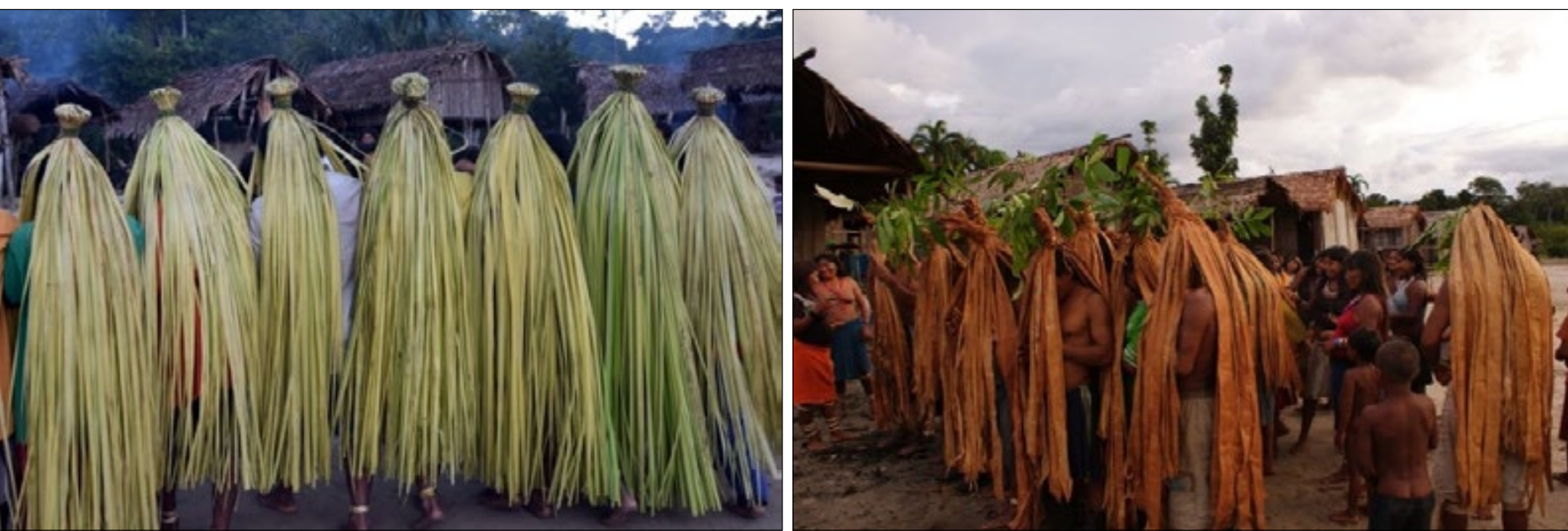

Figura 2 - Roupas masculinas especiais utilizadas durante rituais: A) roupas elaboradas com buriti (Mauritia flexuosa, ihkira); B) roupas elaboradas com entrecasca de árvore não identificada. Fotos: Larissa Tukano (2017) (A); Myrian Barboza (2009) (B). 
infestação de piolhos possuíam cabelos curtos. Durante nossa expedição, quando Larissa fez tranças nos cabelos de várias mulheres Katukina, elas rapidamente desfizeram. Socorro Katukina declarou que elas não se identificavam com aquele penteado, pelo fato de haver exposição de suas orelhas, considerada uma estética imprópria e sem beleza. A restrição do acesso aos microterritórios masculinos é seguida fielmente entre as Katukina, pelo receio de punições futuras associadas à perda de um componente vital de seus corpos e de alto valor estético, o cabelo. Novamente, elementos corporais, essenciais na alteridade feminina, estão presentes nas normativas regentes da corpoterritorialização Katukina.

Entre as/os Kanamari, Costa (2007:325) menciona que aquelas/es que possuem cabelos bonitos, ao contrário de calvície e cabelos grisalhos, correspondem a pessoas não raivosas, que possuem uma vida tranquila. Todavia, durante o período de menarca, primeiro fluxo menstrual onde o corpo é tomado pela matériaalma, as mulheres devem cortar o cabelo para que este não cresça grisalho e frágil, e para evitar o envelhecimento precoce (Costa 2007:328-329).

Entre as Krahô, existe uma restrição de corte de cabelos para as mulheres gestantes, principalmente durante a primeira gestação, a fim de evitar prévio embranquecimento de seus cabelos (Krahô 2017). Todavia, ocorre o corte logo após o seu resguardo, representando fortalecimento do corpo. Nas palavras de Creuza Krahô (2017:47), “O cabelo concentra vários resguardos, o cabelo longo sinaliza que a pessoa está vivendo um tempo especial de cuidado com seu corpo. O cabelo deve ficar grande e ser cortado para que a pessoa tenha saúde, fique alegre novamente”. O resguardo gestacional - que inclui restrição alimentar e de corte de cabelo, bem como ida para determinados locais - possibilitará posteriormente para as Krahô "um fortalecimento do corpo e uma memória corporal", além de amadurecimento pessoal, que propiciará maior participação e sociabilidade na vida coletiva (Krahô 2017:49).

No caso do hokanin, Jaime revelou que, neste local, os homens brincam, conversam, usam muito rapé e descansam antes de irem para a praça da aldeia, o que também foi verificado pelo antropólogo Deturche (2009). Normalmente, o microterritório masculino hokanin localiza-se na parte posterior das aldeias (Figuras 3A e 3B). Os Katukina permitiam que nós, autoras mulheres, Larissa e Myrian, visitássemos estes espaços durante o preparo de suas vestimentas (Figuras $4 \mathrm{~A}$ a $4 \mathrm{D})$. 

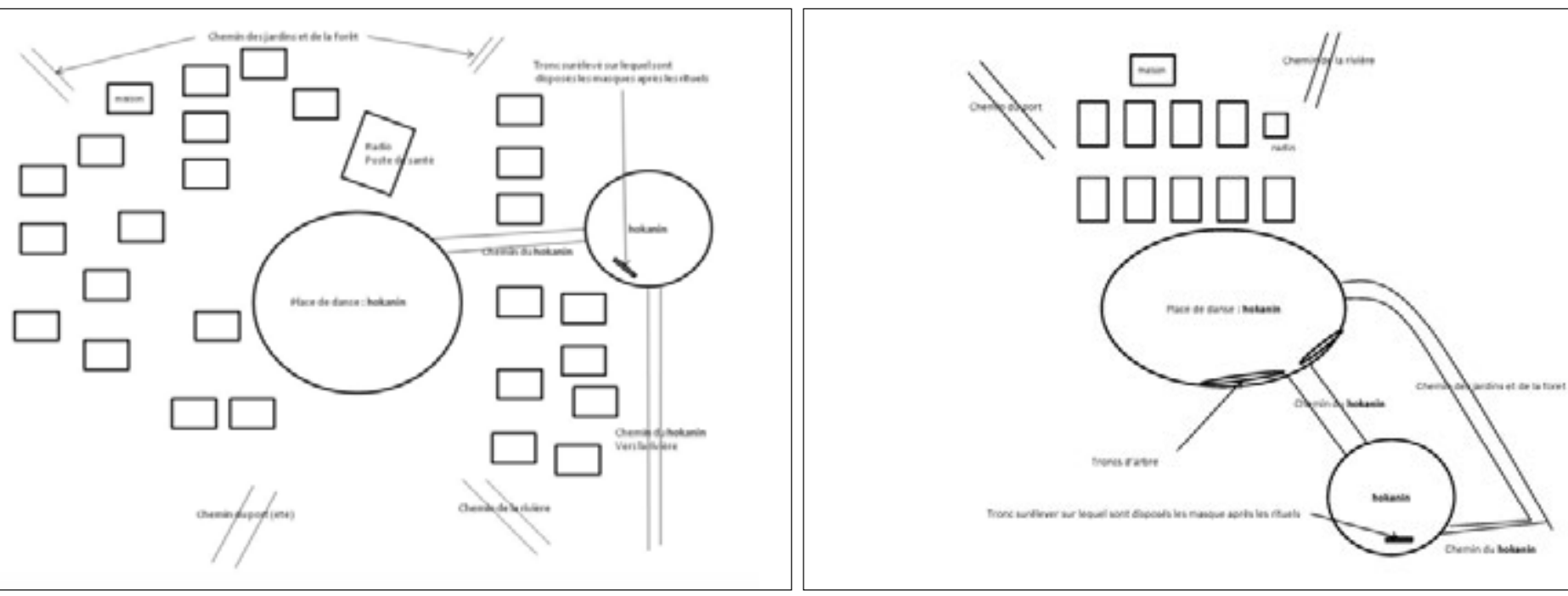

Figura 3 - Localização do microterritório Hokanin: A) aldeia Gato, em 2006; B) aldeia do Pilão, em 2004. Fonte: Deturche (2009:258).

A
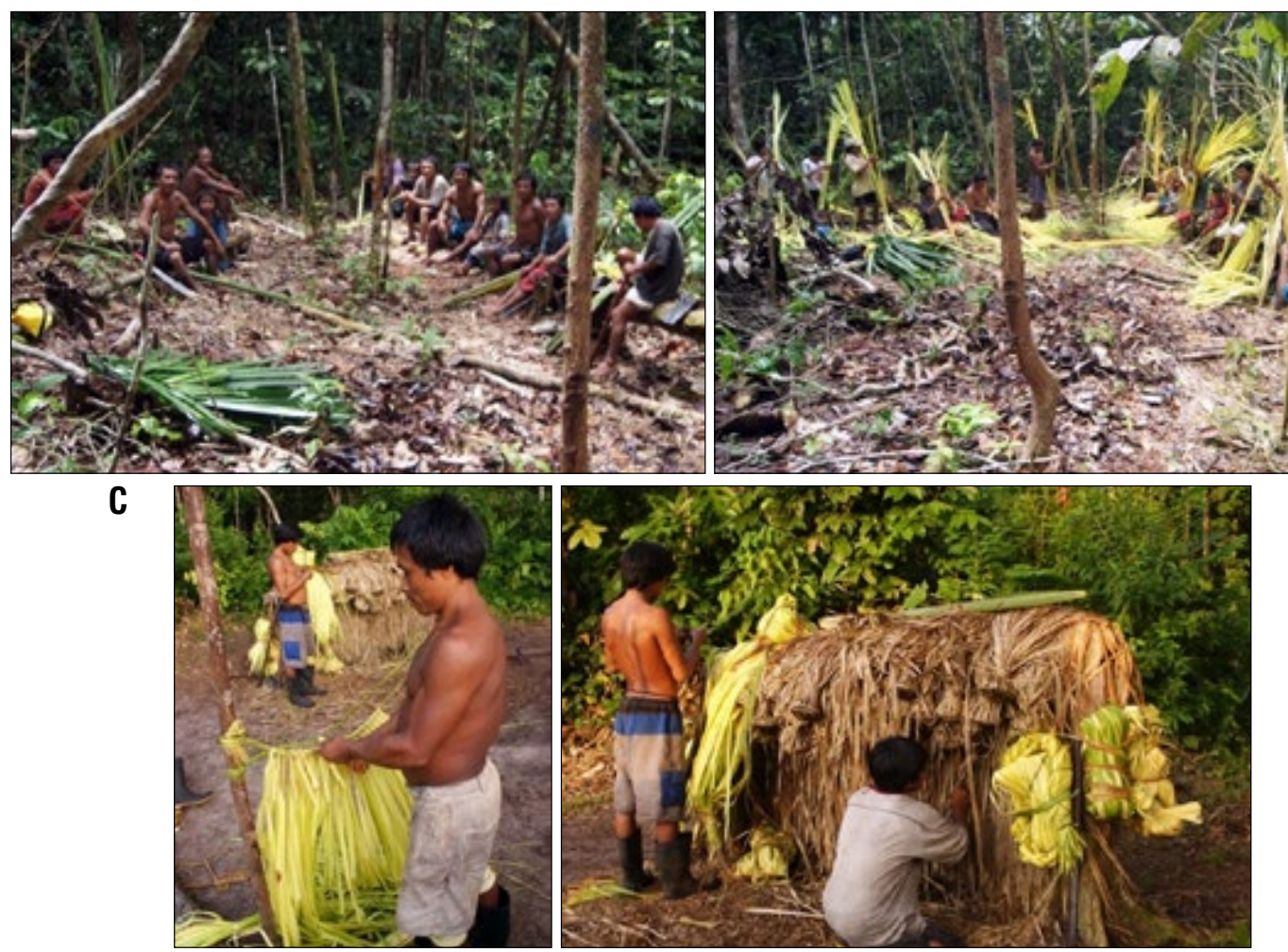

Figura 4 - Hokanin, microterritório masculino, onde os homens Katukina preparam suas vestimentas ritualísticas: A) homens Katukina no início do preparo de suas roupas; B) continuidade do preparo das roupas; C) Auri Katukina finalizando suas novas roupas; $\mathrm{D}$ ) novas roupas penduradas temporariamente junto às antigas roupas descartadas em estrutura específica. Fotos: Jaime Waiwai (2016) (A e B) e Myrian Barboza (2017) (C e D). 
Na aldeia Bacuri, o hokanin localizava-se atrás das casas, ao lado do caminho de acesso para a roça, e podia ser facilmente visualizado. No período dos rituais, as mulheres Katukina só podem acessar o hokanin para realização específica de limpeza, uma vez que os proprietários destes espaços, Wai wara $^{19}$ (Figura 5B), ficam zangados caso o local esteja sujo. No entanto, as mulheres não devem se demorar lá; de acordo com as Katukina, "as mulheres só podem ir lá limpar e voltar rápido”. $\mathrm{Na}$ aldeia Bacuri, Juliana Katukina, oriunda da aldeia Terra Alta e recém-casada, foi responsável pela varrição do microterritório do hokanin. Como ela ainda não possuía filhos - fazia poucos dias que se mudara para aldeia - e era procedente da aldeia Terra Alta, Juliana ocupava uma posição mais submissa em relação às outras mulheres casadas, progenitoras, e muitas eram oriundas da própria aldeia Bacuri. Além disso, Juliana Katukina não se encontrava no período de menstruação e nem de puerpério, correndo, então, menos risco, em comparação com as mulheres que se encontravam em algum destes ciclos.

Percebemos que, para além da limpeza do hokanin, as mulheres Katukina mais velhas também delegavam a Juliana a função de limpeza da praça central e auxílio mais intenso no preparo dos alimentos, diariamente e nos preparativos de

A
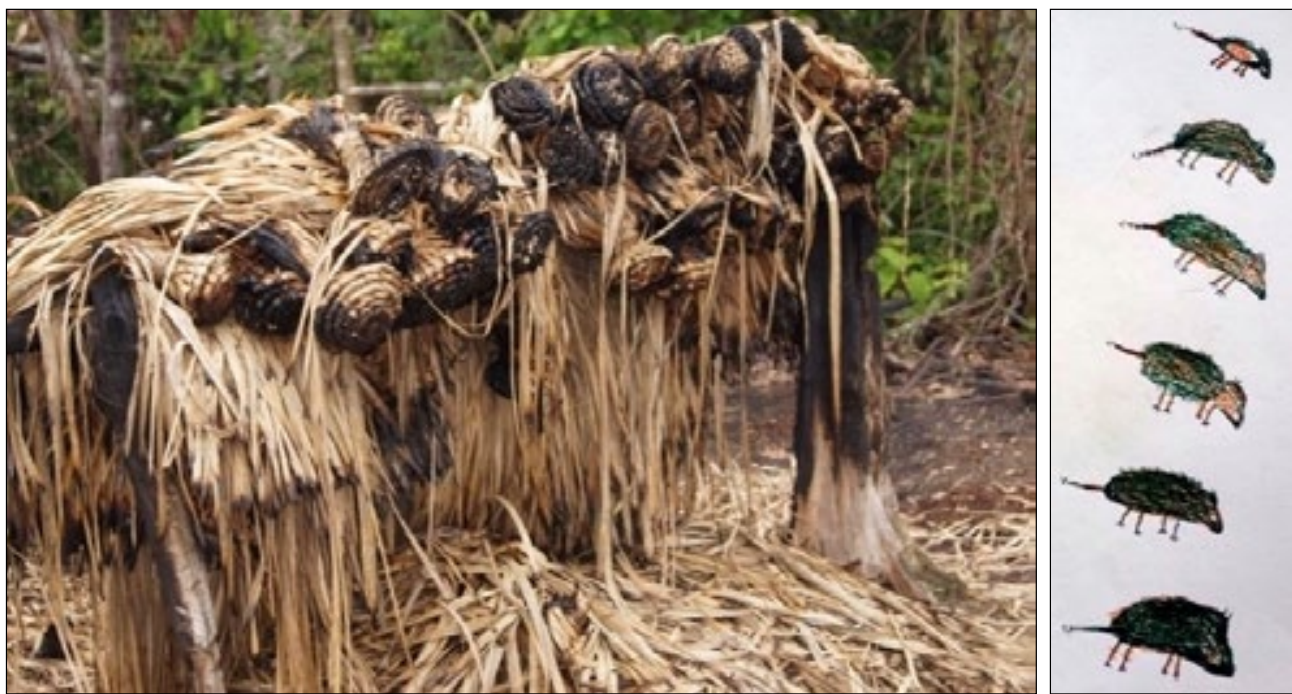

B

Figura 5 - Elementos do microterritório hokanin: A) roupas masculinas armazenadas no hokanin após ritual; B) seres intangíveis, Wai wara, que são donos do hokanin. Foto: Jaime Waiwai (2016) (A). Ilustração: Cacheiro Katukina (2017) (B).

19 Os Wai wara vivem abaixo das roupas ritualísticas antigas que são estocadas uma sobre a outra, acima de um toco de madeira no hokanin (Figura 4D). Essas roupas não devem ser usadas novamente, permanecendo no hokanin até se decomporem (Figura 5A). 
festas. Em julho de 2017, durante uma expedição de 18 dias ao alto rio Biá, por meio de um canoão chalana, contendo a maioria das famílias da aldeia Bacuri, Juliana posicionava-se mais próxima das crianças, distanciada das outras mulheres. Juliana demonstrava-se tímida, porém sempre estava encarregada de algum serviço. Nesta viagem, ela foi aos poucos interagindo com as outras adolescentes (praticamente todas já eram mães) e conosco, porém não falava muito e, durante nossas conversas, respondia com muitos sorrisos.

\subsection{MICROTERRITÓRIOS FEMININOS:}

\section{APARENTEMENTE "OCULTOS", MAS PRESENTES}

Ao contrapor a existência dos microterritórios femininos proibidos aos homens, em relação aos exemplos citados acerca dos microterritórios masculinos proibitivos para as mulheres (ihkira horo e hokanin), tanto as mulheres como os homens Katukina negaram tal possibilidade. No entanto, percebemos que os homens Katukina evitavam a ida ao microterritório onde as mulheres passavam muito tempo preparando acessórios rituais e conversando, como trilhas ou capoeiras (antigas aldeias) de acesso à roça. Nos microterritórios femininos, durante a realização dos rituais, na praça central da aldeia, os homens não transitavam nestes locais, da mesma forma que as mulheres não transitavam nos microterritórios masculinos da praça central.

$\mathrm{Na}$ antiga aldeia Bacuri, após a coleta de produtos agrícolas para preparo de alimentação ritual, as mulheres Katukina decidiram realizar uma parada na área onde localizavam-se as casas da antiga aldeia Bacuri. Atualmente, o espaço compreende uma ampla capoeira, com um imenso campo aberto, composta por vegetação arbustiva frutífera e gramíneas, que precede o caminho de acesso às roças (Figuras 6A a 6C). Inicialmente, não tínhamos compreendido o motivo da pausa em um local aberto, com muita incidência solar e extremamente quente, logo após um dia de trabalho intenso e cansativo. Posteriormente, cogitamos que aquela situação representava uma assinatura territorial feminina, situação também observada na aldeia Sororoca, quando as Katukina realizaram procedimento similar de parada para descanso, brincadeiras e elaboração de acessórios rituais (pulseiras), logo após retornarem da roça, em uma trilha na mata. Assim, aparentemente “ocultos”, os microterritórios femininos são menos evidencializados em comparação com os masculinos, porém eles existem e possuem assinatura territorial feminina própria. 
A
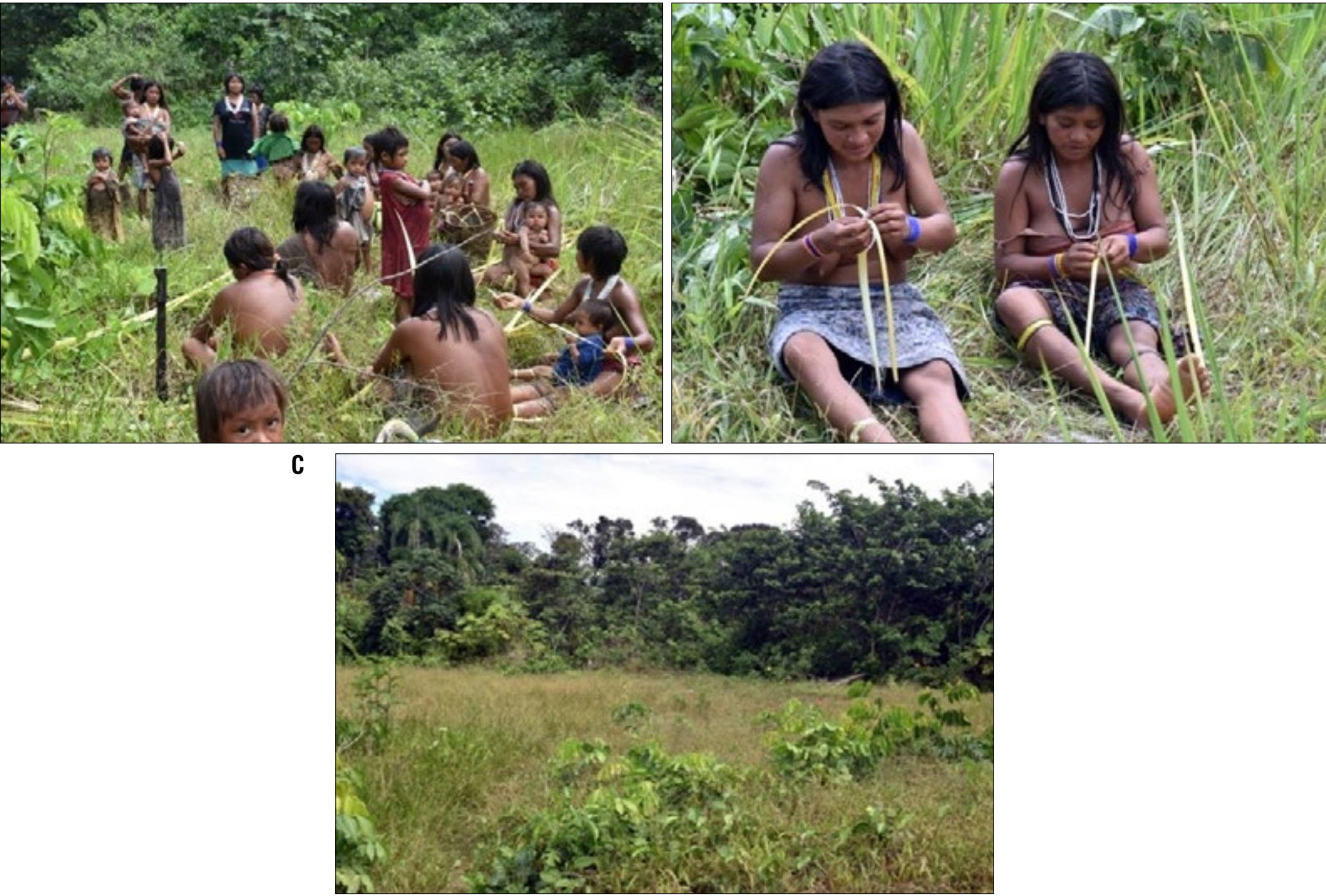

Figura 6 - A) Mulheres Katukina no microterritório feminino; B) Maria de Jesus Katukina e Rosa Katukina; C) microterritório feminino. Fotos: Larissa Tukano (2017).

\subsection{MICROTERRITÓRIOS "ANTAGÔNICOS"}

Além dos microterritórios femininos e masculinos, situados em áreas relativamente distantes uns dos outros, observamos alguns desses ambientes localizados no mesmo espaço, na praça central da aldeia, porém em extremidades opostas, o que é comum entre alguns grupos indígenas das terras baixas sul-americanas (Costa 2007; Lasmar 1996, 2005). Os homens e as mulheres posicionamse em direções antagônicas desde a chegada na praça, durante o preparo e a organização do espaço. As mulheres instalam redes em uma das extremidades, enquanto os homens inserem um grande tronco no chão, do lado oposto, que 
funcionará como um banco para assento (Figura 7A). Por isso, denominamos estes microterritórios como "antagônicos".

Primeiramente, no meio da praça central, os homens iniciam o consumo de koya, bebida ritualística não fermentada. Na sequência aparece o grupo de mulheres, que também ingere a bebida, mas oriunda de outros recipientes (panelas). Depois, os homens retornam ao hokanin, onde continuam suas conversas e brincadeiras. Mais tarde, eles, de mãos dadas e acompanhados pelos filhos meninos, vão para o meio da praça, onde iniciamo canto e a dança. As mulheres aparecem e se posicionam em frente aos seus parceiros, para acompanhamento da A dança e dos cantos. São formadas duas filas antagônicas: mulheres de mãos dadas lado a lado, e a fila masculina, com homens também posicionados de mãos dadas lado a lado (Figura 7A).

Ao longo da noite, as/os Katukina realizam várias pausas: os homens se concentram no canto oposto das mulheres para insuflarem rapé, sentados no banco ou no chão (Figuras 8B e 8C), enquanto as mulheres ocupam suas redes no canto oposto, onde ajeitam seus acessórios e pinturas corporais, acompanhadas por garotas e crianças (Figuras 8A e 8C). Durante alguns momentos, as/os Katukina param no centro da praça para novamente beber koya, sendo que a festa dura a noite inteira, até o amanhecer (Barboza 2019; Deturche 2009).

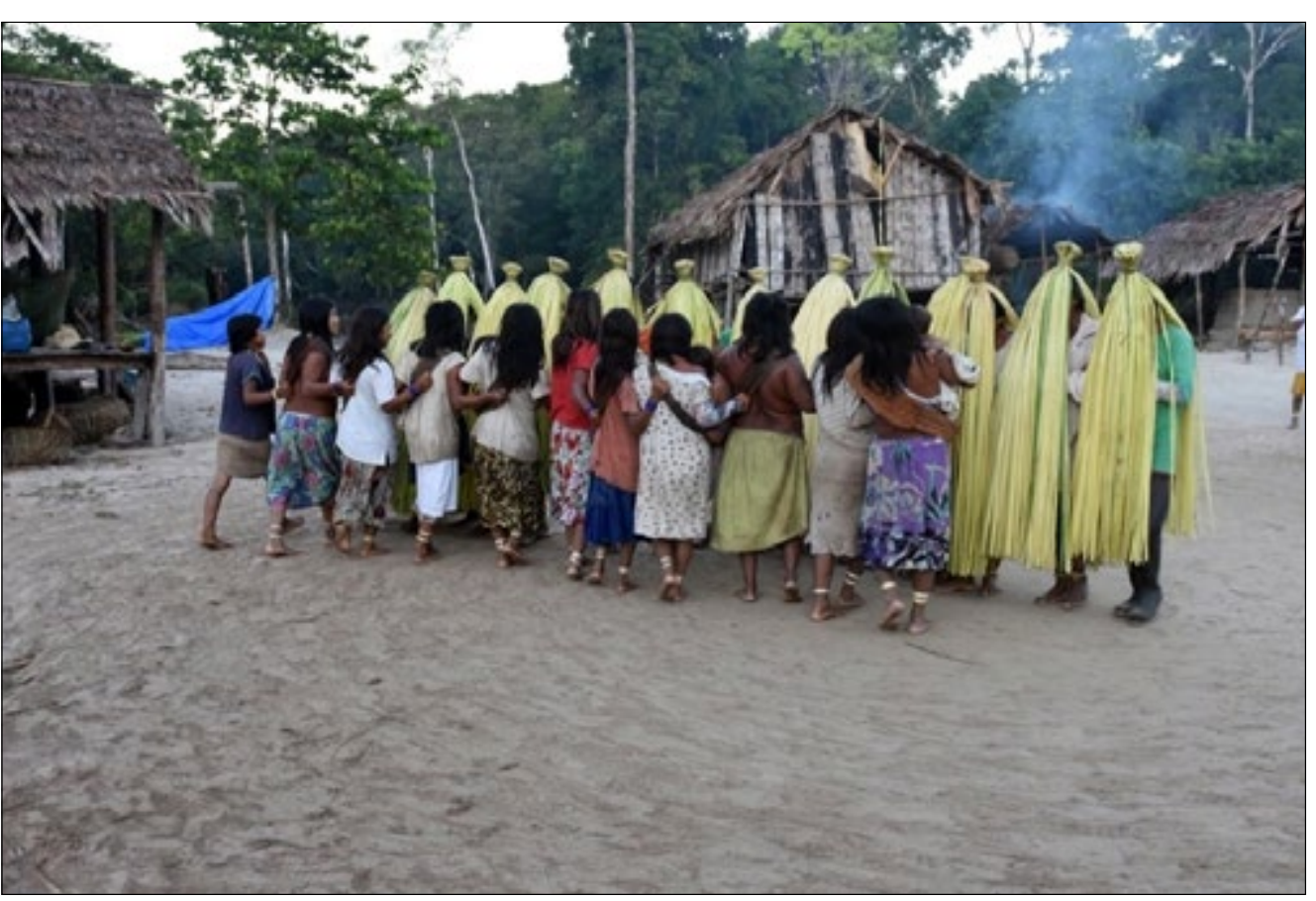

Figura 7 - Ritual Katukina: A) filas antagônicas durante o ritual; B) casal Katukina com vestimentas ritualísticas. Foto: Larissa Tukano (2017) (A). Ilustração: Larissa Tukano (2018) (B). 
A
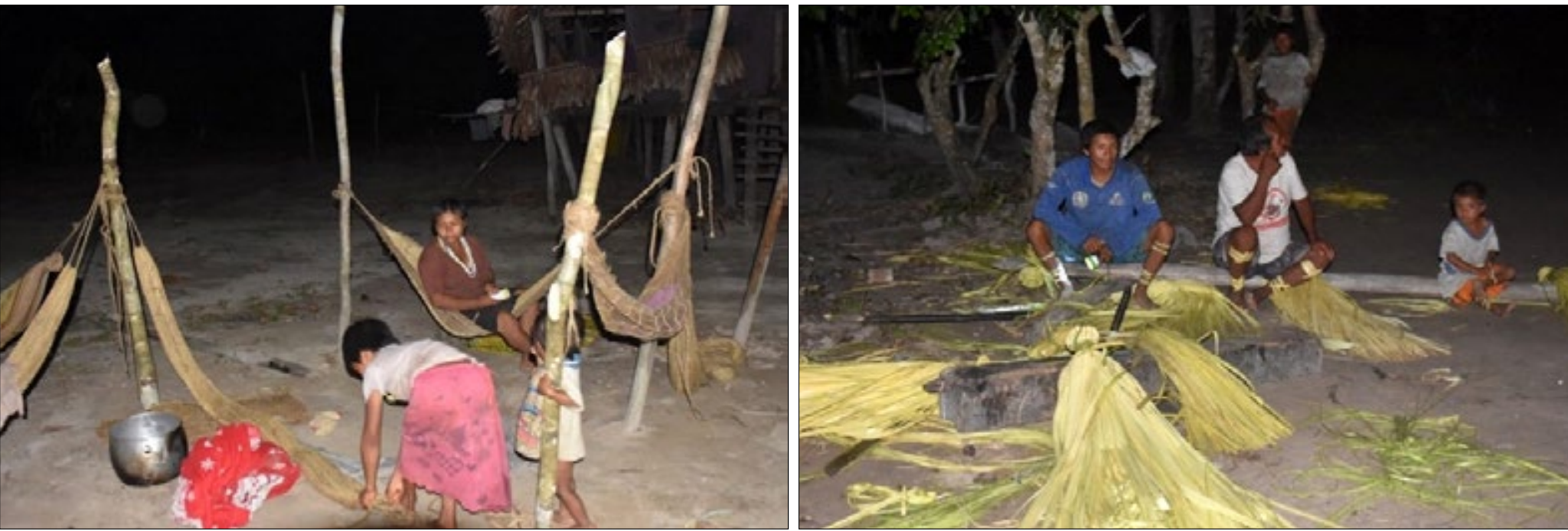

C

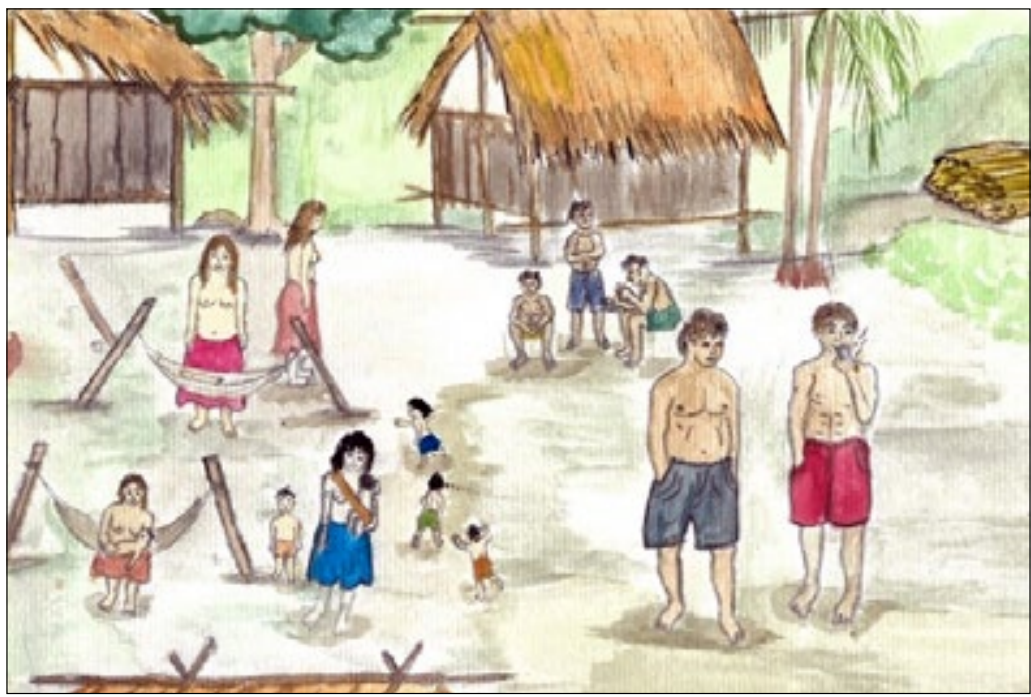

Figura 8 - Microterritórios "antagônicos": A) mulheres e meninas no lado oposto; B) homens e meninos; C) mulheres, homens e crianças nos microterritórios "antagônicos" na praça central durante o ritual. Ilustração: Larissa Tukano (2017).

\section{ASSINATURAS SENSORIAIS DA}

\section{“CORPOTERRITORIALIZAÇÃO” KATUKINA}

Também utilizamos a concepção de território aplicada por Deleuze \& Guattari (1987) porque contempla a noção de fatores de territorialização sensorial, fortemente presentes entre as/os Katukina.
Diversos fatores, como cor, som, odor, canto, silhueta e outros, atuam no processo de territorialização. Como exemplo de ações de marcação do território, Deleuze \& Guattari (1987:315) descrevem os peixes que exibem cores expressivas e rítmicas; as aves que diariamente, pelas manhãs, cantam; ou, ainda, as 
aves que viram as folhas caídas no solo para que a tonalidade da face inferior contraste com a coloração do solo. Na etologia, disciplina da biologia que estuda o comportamento animal, existem vários exemplos de marcações territoriais realizadas por animais. Por exemplo, a marcação de urina feita pelos cachorros (Canidae) e pelos saguis (Callithrix sp.), que urinam e esfregam partes de seus corpos, através de glândulas odoríferas, nas árvores (Ryland 1982). Assim, estas assinaturas olfativas sinalizam sua presença e o uso no/do território para repelir adversários ou atrair futuras/os parceiras/os sexuais.

Entre as/os Katukina, verificamos um vasto repertório de assinaturas sensoriais olfativas, visuais e sonoras ${ }^{20}$ da corpoterritorialização Katukina. Uma parte destas assinaturas, essencialmente visuais, se constitui como procedimentos de exibição do uso do microterritório, uma marcação territorial entre os diferentes grupos Katukina, principalmente entre as aldeias. Uma forma de comunicar visualmente a presença, o uso e o limite territorial. Enquanto outras assinaturas, olfativas e visuais, têmo propósitode impedir conflitos junto aos seres intangíveis, constituindo-se também como medidas sensoriais protetoras contra estes seres. Destarte, as/os Katukina "marcam" sua invisibilidade para não serem encontradas/os por estes seres. Uma maneira de se tornarem despercebidas/os em determinados territórios. A seguir, apresentamos e discutimos algumas destas assinaturas sensoriais olfativas e visuais.

\subsection{ASSINATURAS SENSORIAIS OLFATIVAS}

As/Os Katukina possuem um conjunto de medidas sensoriais protetoras contra os seres intangíveis ${ }^{21}$ relacionadas principalmente à acurada capacidade olfativa $^{22}$ destes seres. Esta eficácia olfativa lhes permite encontrar as/os Katukina até mesmo em localidades distantes. Dessa maneira, as/os Katukina ficam extremamente cautelosas/os durante condições biológicas femininas, como puerpério e menstruação, ou atividades de captura de animais que emanam odores fortes, como pescarias com uso de plantas tóxicas (timbó) e caçadas demoradas, que prolongam a liberação do sangue do animal quando este é atingido

20 Durante os rituais as/os Katukina realizam inúmeros cantos que provavelmente correspondem a assinaturas de corpoterritorialização. Elas/es alegaram que devem realizar os rituais com fartura de comida, danças e cantos, para que os seres intangíveis não fiquem brabos. No entanto, não realizamos análise desses cantos. Tivemos a informação de que o antropólogo Kaio Hoffman (comunicação pessoal, 2014) está desenvolvendo estudos sobre cosmologia dos rituais Katukina em seu doutorado em antropologia (UFSC).

21 Em sua tese de doutorado, Myrian Barboza oferece um capítulo inteiro, "Every place has an owner!": intangible beings and Katukina relationships and the gendered appropriation, use, and sharing of territories", sobre as questões de maestria entre as/os Katukina.

22 No entanto, não conseguimos verificar entre as/os Katukina se os seres intangíveis possuem um cheiro peculiar ou distinguível, reconhecido por elas/es. 
e ferido, mas ainda consegue escapar. Estas assinaturas de territorialização também se constituem como fatores limitantes de acesso e de uso temporal de determinados microterritórios.

No decorrer do período das circunstâncias biológicas femininas, não apenas o trânsito feminino é restringido, como também a mobilidade do esposo, do recém-nascido e das crianças de colo. Logo após o parto, o casal e o bebê devem permanecer reclusos em casa e respeitar as normas restritivas ${ }^{23}$ para determinadas atividades e alimentos. Após alguns dias, o homem pode locomover-se dentro da aldeia, porém a mulher deve continuar de resguardo em casa, recebendo visitas dos familiares mais próximos. Ao longo deste período, ambos devem tomar banho dentro de casa e evitar a ida para floresta, rio, roças e outros microterritórios. Os familiares (cunhada, irmã e avó) ficarão responsáveis pelo provimento de água e alimentação especial, além do cuidado com as outras crianças do casal. Assim, por causa da capacidade de transferência do cheiro feminino para os homens, os homens Katukina possuem ritos de parto ou couvade (Rival 1998:622), que consistem nas restrições de dieta e atividade perinatal (antes e depois do parto) para ambos, pai e mãe. Novamente, o corpo feminino atua no controle da mobilidade e da alimentação de toda a família.

As mulheres Katukina apreciam vigorosamente a chegada do bebê, que consiste em um importante evento. Em algumas destas ocasiões, nós, autoras mulheres, fomos convidadas para visitar a mãe e o recém-nascido. Durante a visita, verificamos que o cordão umbilical do bebê se encontrava pendurado na rede e havia, ali próximo, um pequeno fogareiro ${ }^{24}$ de barro, contendo resina de breu em sua cavidade superior (Figura 9). Posteriormente, uma enfermeira não indígena relatou que as mulheres Katukina, durante o resguardo do pós-parto, posicionam o fogareiro entre suas pernas, direcionando a fumaça do breu para a vagina, a fim de acelerar o processo de cicatrização. Este procedimento também provoca emissão de forte e agradável cheiro proveniente do breu. Assim, as mulheres Katukina precisam passar por um processo de cicatrização adequada, que envolve uso de uma resina de forte fragrância e que lhes permite recuperação, para posterior saída de casa e enfrentamento do "mundo externo", repleto de seres intangíveis.

23 Atualmente, muitas/os jovens Katukina, principalmente da região do baixo rio Biá, não vêm considerando estas regras, conforme lamentações das/os Katukina mais velhas/os (Barboza 2019).

$24 \mathrm{O}$ fogareiro assemelha-se a um pequeno vaso de cerâmica, sendo utilizado para queima, assamento e/ou cozimento de alimentos. A superfície inferior contém uma cavidade para armazenar carvão, enquanto o topo contém outra cavidade para conter resina ou o alimento. As bordas superiores formam uma base que pode sustentar uma grelha ou panela. A função geral do fogareiro é assar ou cozinhar peixe, sendo facilmente encontrado nos mercados públicos da Amazônia (Figuras 9A e 9B). No entanto, o fogareiro Katukina é mais simples e rústico. As características deste objeto, como tamanho e facilidade de transporte, permitem seu uso nos barcos. 

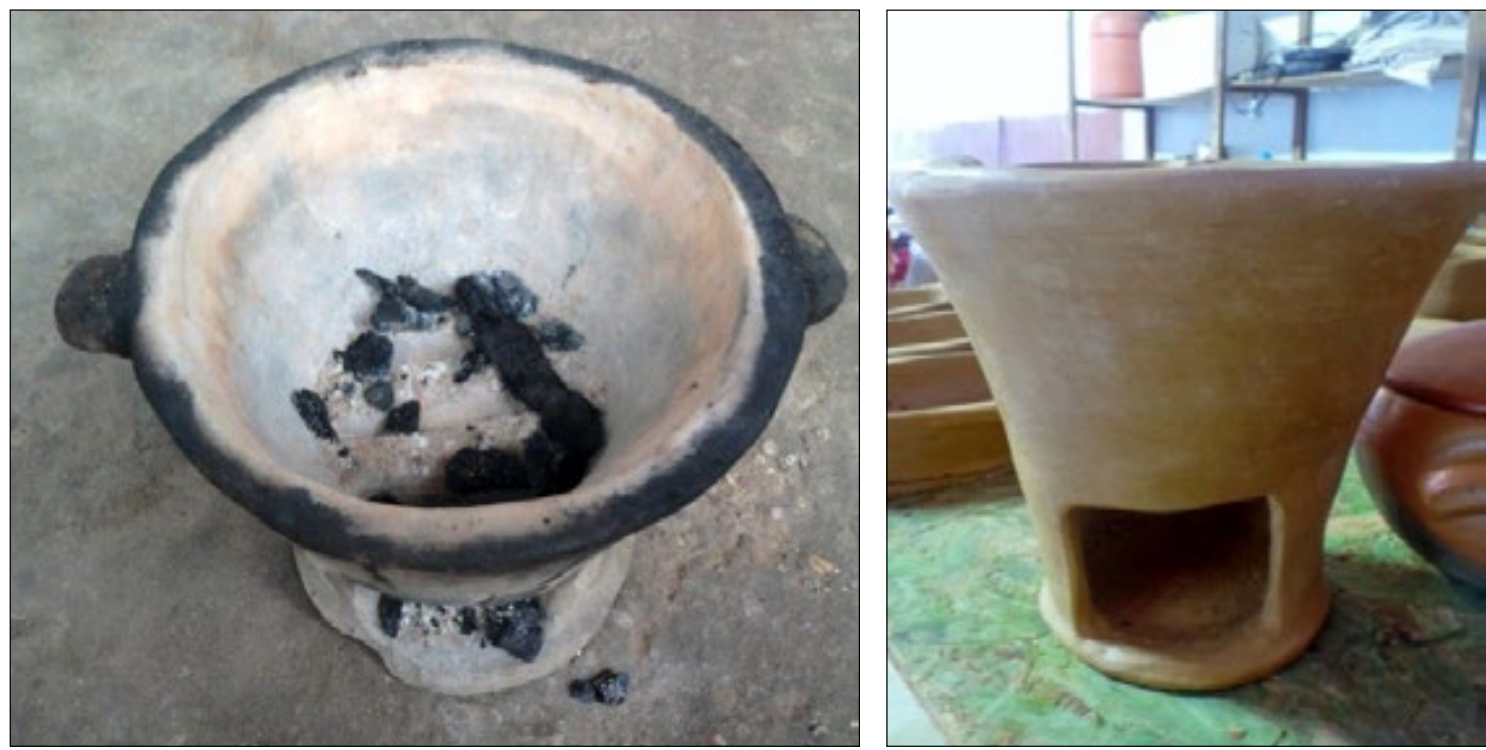

Figura 9 - Fogareiros da região amazônica: A) fogareiro encontrado em mercado público no estado do Amazonas (http://putirapuranga.blogspot.com); B) fogareiro Macuxi (http://www.letrassaborosas.com.br/2013/11/ceramicamacuxi-uma-arte-milenar-folha.html).

No decurso do ciclo menstrual, as mulheres Katukina e seus parceiros não devem ir a rios, roças, capoeiras e floresta. Durante uma expedição ao alto rio Biá, verificamos que um jovem casal tomava "banho de cuia" ${ }^{25}$ na área onde realizamos pausa para preparo do almoço (Figura 10). O jovem iniciou o banho com água proveniente do rio, coletada por sua mãe e irmã, já que sua esposa se encontrava no período da menstruação. Nesta fase, o casal não deve ter contato com o rio, para evitar a sua descoberta por parte de seres intangíveis. De acordo com Deturche (2009:324), no período menstrual e puerperal, as mulheres Katukina devem evitar a disseminação do cheiro do sangue feminino, que é transmissível ao marido, por meio da relação sexual e do tato, e às crianças, pelo tato. Assim, as mulheres Katukina devem controlar a transmissão do cheiro do seu sangue, devendo ficar separadas do parceiro nesta fase (Deturche 2009:324-325).

Para Braulina Baniwa (2018:168), durante as regras femininas, as mulheres devem realizar limpeza do corpo, pois o cheiro do sangue menstrual é considerado "um veneno para olhos dos homens e seres espirituais do mato, dos rios, do ar, que chamamos de donos dos lugares ou seres invisíveis". Durante o puerpério das mulheres Guarani, Sandra Benites (2018:12) também relata a importância das restrições alimentares e de movimento por

25 Expressão muito utilizada na região amazônica e no Nordeste brasileiro, em referência ao banho realizado com uso de uma cuia (Crescentia cujete ou um recipiente pequeno) e um balde cheio de água. Por meio da cuia, a água do balde é retirada e jogada ao corpo. As/Os Katukina utilizaram cuia e uma panela de alumínio. 


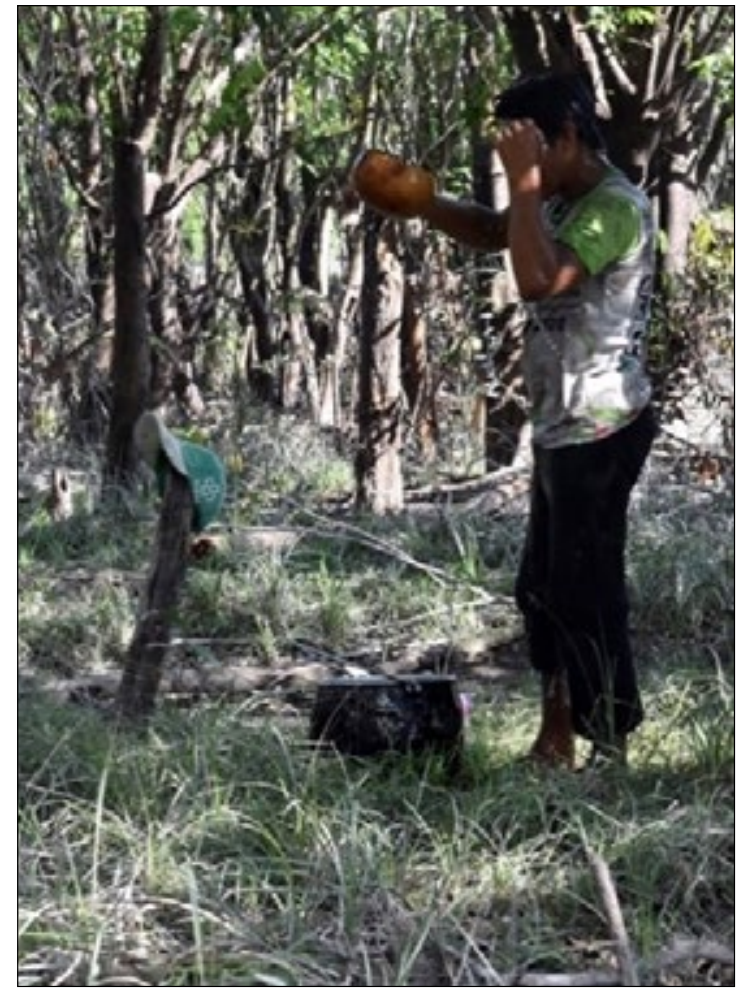

Figura 10 - Alexandre Katukina tomando "banho de cuia" durante o ciclo menstrual de sua esposa.

Foto: Larissa Tukano (2017).

parte do marido, a fim de evitar ser capturado por "mba'e dja", o dono das coisas. Conforme Belaunde (2006:207), na Amazônia, o sangue feminino opera internamente e externamente ao seu corpo, sendo que o sangramento pós-parto é o mais temido, "por acarretar perigos espirituais para toda família e todos aqueles que compartilham a sua existência”. Belaunde (2006:218) alega que o sangue feminino atua como operacionalizador, fortemente relacionado com os mestres da Amazônia, mas que também transporta conhecimento corporificado.
Atividades de pesca com uso de plantas venenosas, como o timbó, também devem ser realizadas de maneira cautelosa (Figuras $11 \mathrm{~A} \mathrm{e}$ 11B). Assim, as/os Katukina evitam permanência prolongada no local desta atividade e, após finalizada, elas/eles retornam para aldeia, para realização de procedimento especial de remoção do cheiro da planta que ficou em seus corpos. Durante nossa expedição ao alto rio Biá, imediatamente após o nosso retorno da pescaria com timbó, famílias Katukina inteiras providenciaram o banho no rio com uso abundante de sabão, especialmente o nosso sabão em pó ${ }^{26}$, adquirido na cidade de Jutaí, inicialmente para fins de lavagem de roupa. De acordo com elas, o sabão em pó possui cheiro mais forte, o que o torna mais eficiente no processo de limpeza. As/ Os Katukina também recomendam o uso de breu durante as atividades de caça, a fim de repelir os donos das caças. Quando a mulher se encontra em seu período menstrual, tanto ela quanto seu esposo devem lavar suas roupas com sabão em pó ou utilizar óleos vegetais em seus corpos.

Os Katukina também revelaram que eles não devem caçar por um longo período, principalmente quando os animais são atingidos, mas conseguem escapar. Quando os animais de caça são lesionados e não morrem imediatamente, liberam o cheiro

26 Desde 2009, quando um dos autores conheceu as Katukina, elas demonstravam fascínio pelo cheiro dos sabonetes emanados durante os banhos nos igarapés. Posteriormente, quando conheceram o sabão em pó, elas sempre solicitavam uso deste produto para lavagem de suas roupas e, principalmente, para limpeza corporal e capilar. 

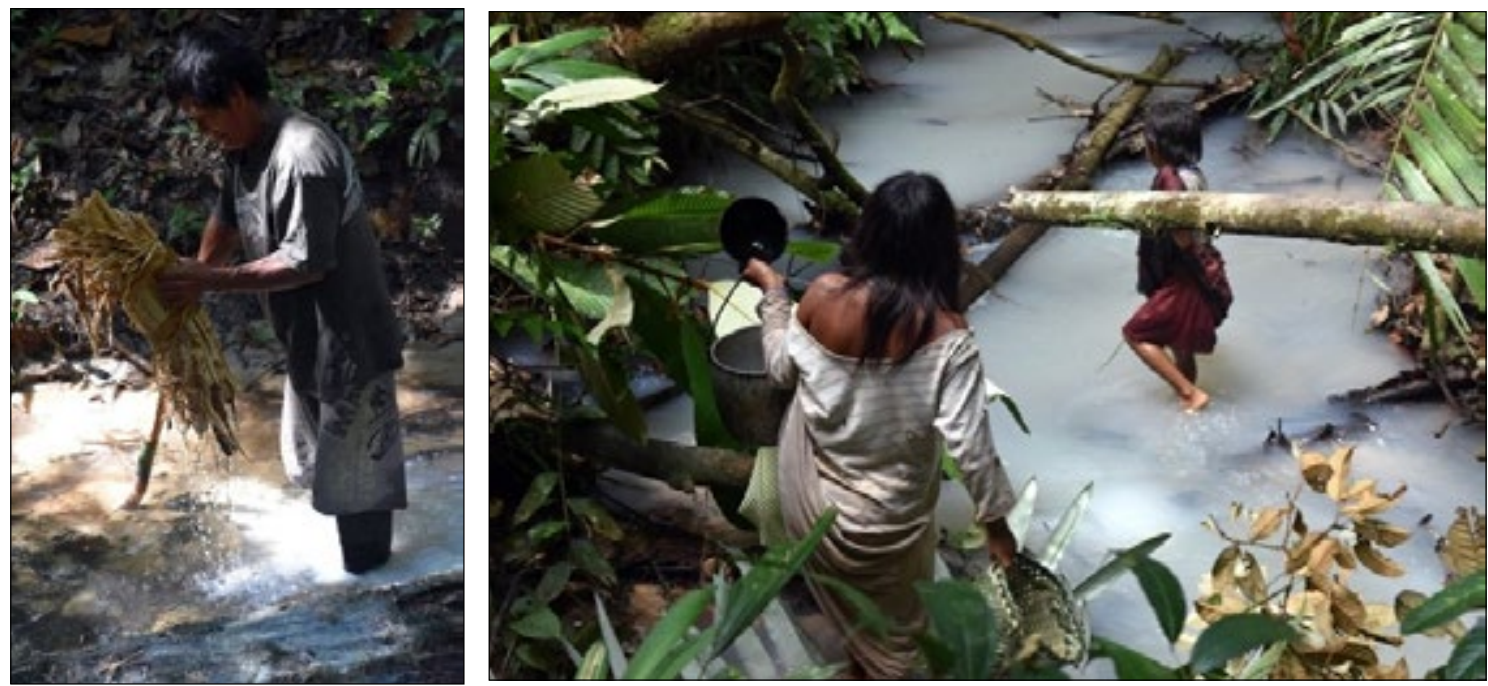

Figura 11 - Pesca com uso de planta tóxica (timbó): A) Dario Curumim Katukina utilizando timbó em igarapé; B) Rosa Katukina com netos coletando peixes envenenados pelo timbó. Fotos: Myrian Barboza (2017).

de sangue por um período maior e contínuo, e, (Figura 12), para não receberem $d y o h k o^{28}$ (pedras) assim, podem ser facilmente detectados pelos seus dos donos das caças e não adoecerem. donos, os seres intangíveis.

Desse modo, as/os Katukina não investem muito tempo na procura de presas feridas e possuem procedimentos especiais para evitar a morte prolongada destes animais ${ }^{27}$. Logo após a captura do animal, os Katukina devem retornar rapidamente $\mathrm{e}$ realizar limpeza do bicho

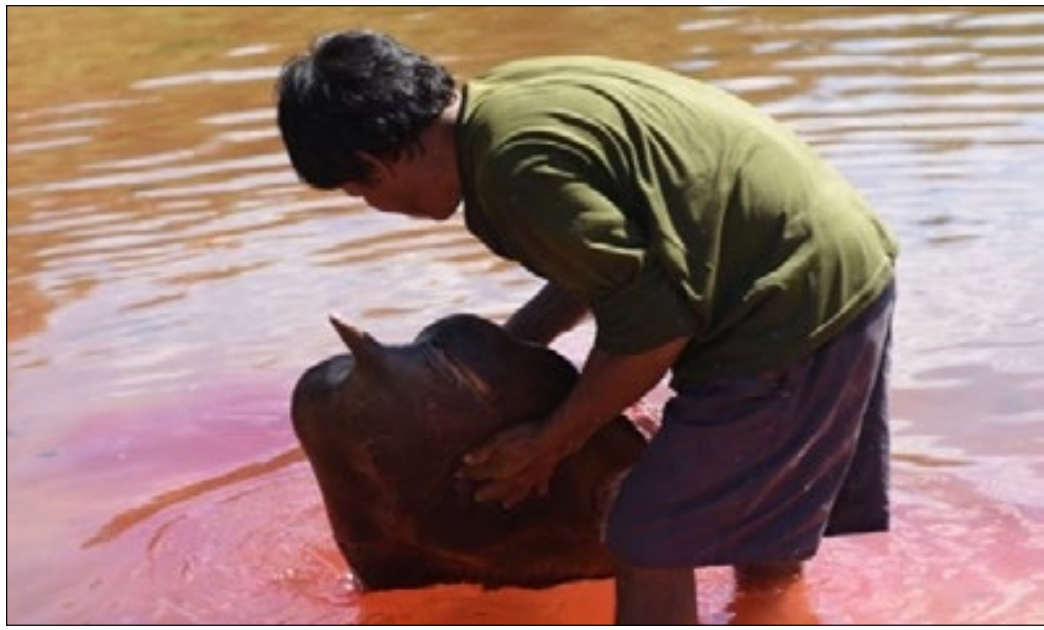

Figura 12 - Carnaval Katukina limpando cabeça de anta (Tapirus terrestris, mok) caçada imediatamente após a chegada no acampamento. Foto: Larissa Tukano (2017).

27 Nas religiões afro-brasileiras, seus praticantes também evitam a morte prolongada e consequente sofrimento dos animais (Kisse Leivas Ti Ogum, pai pequeno do templo religioso de matriz africana Ilê Asê Oyá Dinan Mi Ganbelé; Izonara Santos, Hunsó Omifele do templo religioso de matriz africana Kwe Oto Sindoyá, comunicação pessoal, 2019).

28 Os Katukina possuem um sistema complexo de doença e cura associado aos seres intangíveis e ao xamanismo. Grande parte das doenças é provocada pelos dyohko (pedras), enviadas por xamãs, através de um feitiço mágico com uso de rapé (Barboza 2019:169), que também é comum entre os Kanamari (Costa 2007). 
Outro aspecto importante consiste na realização de atividades de caçadas e coleta de plantas despidos. Durante acompanhamento de uma atividade de caça, Jaime Waiwai e, posteriormente, um enfermeiro não indígena, informaram que os homens Katukina iam gradualmente deixando suas peças de roupa penduradas ao longo da trilha. Para Jaime, caçar nu representa uma atitude estranha, devido à quantidade de mosquitos presentes na floresta. Todavia, os Katukina também solicitaram que Jaime fizesse o mesmo, para que eles não fossem detectados. Nós acreditamos que este comportamento consiste em mais uma estratégia olfativa e visual dos Katukina, devido ao cheiro do suor impregnado nas roupas e à própria coloração chamativa delas, para não serem detectados pelos seres intangíveis.

Durante uma expedição de coleta de tucum (Astrocaryum sp.) ao alto rio Biá (rio Wana an), também presenciamos ações similares de desnudamento das mulheres Katukina (Figura 13). Além dessas situações, também presenciamos as mulheres desnudas durante os rituais noturnos.

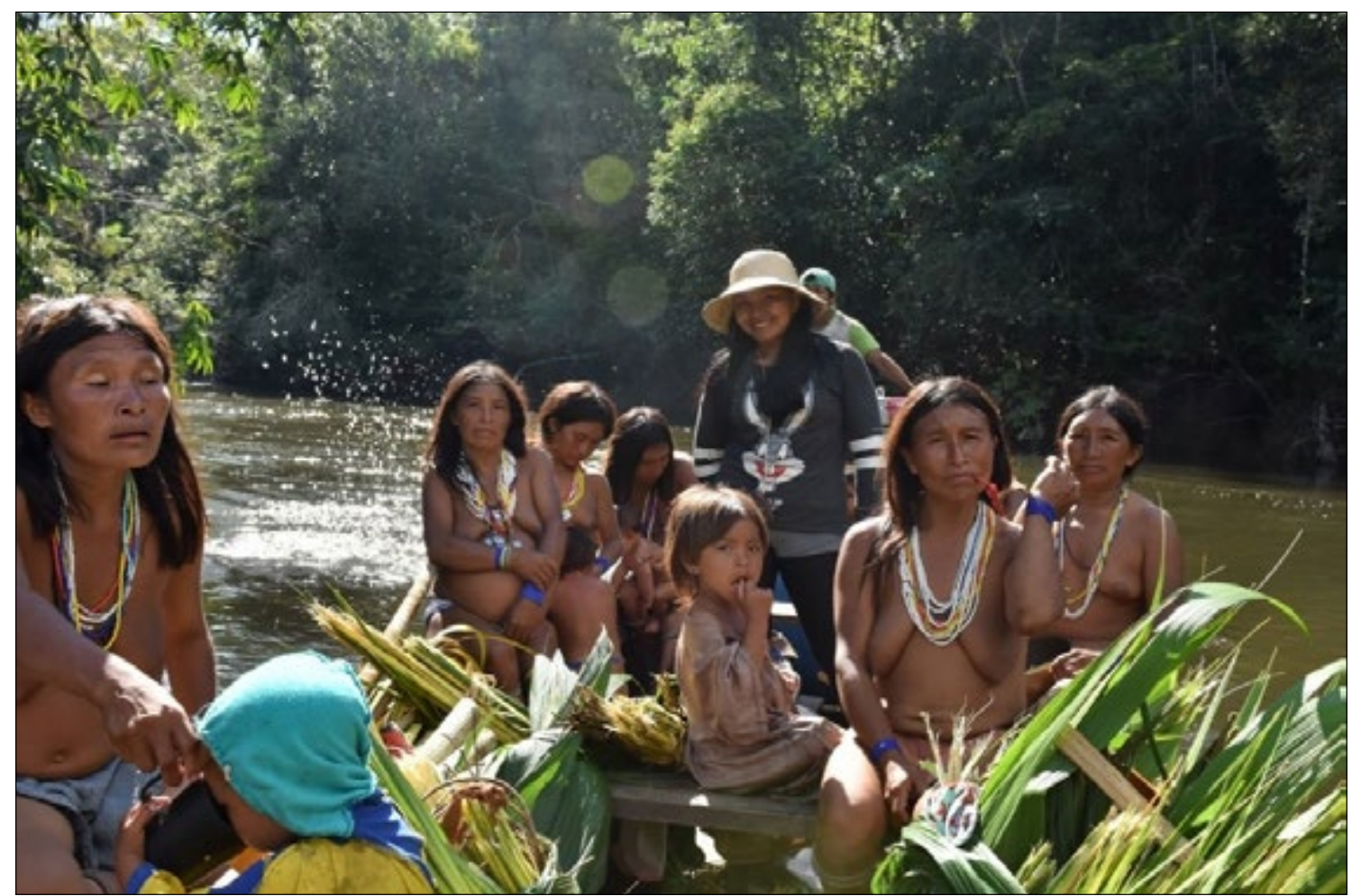

Figura 13 - Mulheres Katukina (Marlene, Maroca, Socorro, Fátima e Rosa) retornando da coleta de tucum (Astrocaryum sp.). Foto: Myrian Barboza (2017). 


\subsection{ASSINATURAS SENSORIAIS FÍSICAS}

Além das assinaturas olfativas, as/os Katukina também assinalam visualmente seu território.

Durante nossas viagens a territórios longínquos, realizávamos acampamentos temporários de dormidas nas praias formadas à margem dos rios. A maioria das praias de longa extensão de faixa de areia, consideradas bonitas pelos Katukina, localizava-se em frente aos remansos ${ }^{29}$. No entanto, os remansos representam locais extremamente perigosos onde vive Panwarahi, o dono deste microterritório e um dos seres mais temidos entre as/os Katukina (Figura 14A). De maneira quase unânime, várias comunidades não indígenas da A região amazônica possuem elevado respeito aos

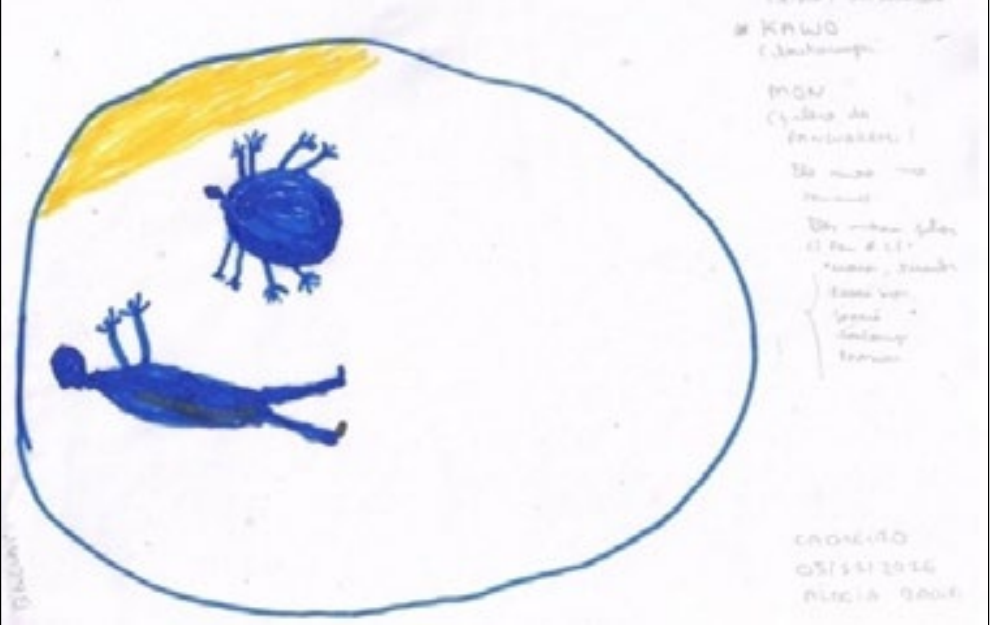

remansos e seus donos. As/Os Katukina também evitam passar próximos de barrancos, locais de alto risco por constituírem a moradia de Houm tehnin wara, outro temeroso ser intangível (Figura 14B).

Nas praias em frente aos remansos, as/os Katukina elaboravam barricadas físicas em volta de suas e de nossas redes para dificultar nossa visualização pelos seres intangíveis, que também possuem impressionante capacidade sensorial visual. Estas barreiras eram constituídas por grandes galhos com folhas ou pedaços de lonas plásticas (Figuras 15A e 15B), dispostos na frente da margem e formando um semicírculo. A parte posterior do arranjo de redes estava posicionada em frente à floresta. Assim, o semicírculo frontal de galhos e lonas, junto à floresta

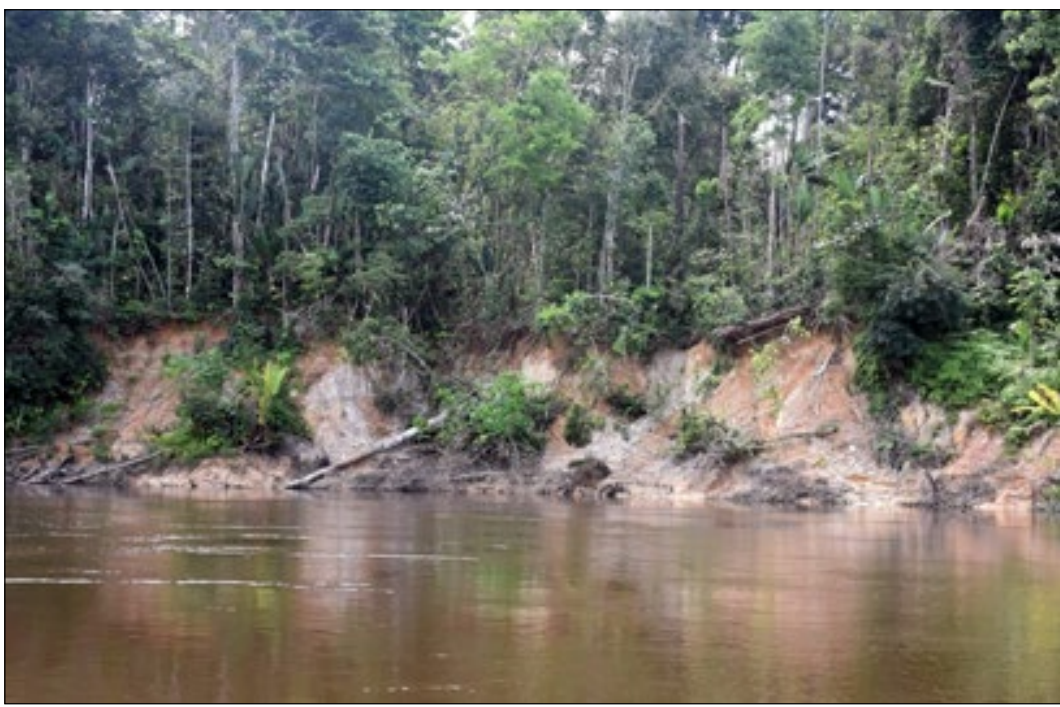

Figura 14 - Microterritórios perigosos: A) remanso, próximo à praia (em amarelo), onde vive o ser intangível Panwarahi; B) barranco onde vivem seres intangíveis. Ilustração: Cacheiro Katukina, Aldeia Bacuri, 2016 (A).

Foto: Myrian Barboza (2017) (B).

29 Remanso significa "refluxo fluvial junto às margens de um rio, decorrente de uma ponta de terra que penetra na água, numa enseada etc.” (Michaelis 2019). 
na porção posterior, funcionava como uma verdadeira trincheira circular protetora.

As/Os Katukina organizavam suas redes longe da margem do rio, enquanto nossas redes (Myrian e Larissa) podiam ser posicionadas próximas à beira. Ressaltamos, no entanto, que nossas redes sempre estavam dispostas à frente das redes das famílias Katukina. Concluímos, portanto, que nossos corpos (Myrian e Larissa), instalados nas redes, também funcionavam como barreiras vivas de proteção às/aos Katukina.

Inclusive, chegamos a brincar com as/os Katukina, afirmando que a onça (Panthera onca) poderia atacálas/los pelos fundos da praia, chegando pela floresta. No entanto, elas/es contra-argumentavam que os botos (Inia geoffrensis ou Sotalia fluviatilis) nos A atacariam pela margem da praia. Definitivamente, as/os Katukina nos usaram como um escudo, estrategicamente posicionado na frente da margem fluvial (Figura 16A). Ademais, quando as praias em frente ao remanso continham trechos arenosos e trechos contendo gramíneas - porém estes últimos se localizavam mais afastados da margem -, as/os Katukina preferiam acampar no meio das gramíneas (Figura 16B). Nestes trechos, as/os Katukina estavam mais susceptíveis a animais peçonhentos e urticantes, como ocorreu em uma noite, quando uma aranha caranguejeira (Theraphosidae) subiu na perna de um Katukina. Mesmo assim, quando advertíamos sobre estes "perigos", as/os Katukina sorriam e ponderavam que ali estavam seguras/os.

Em 2010, Myrian encontrou uma família Katukina acampada à margem de um igarapé, sendo que havia uma barreira com pequenas
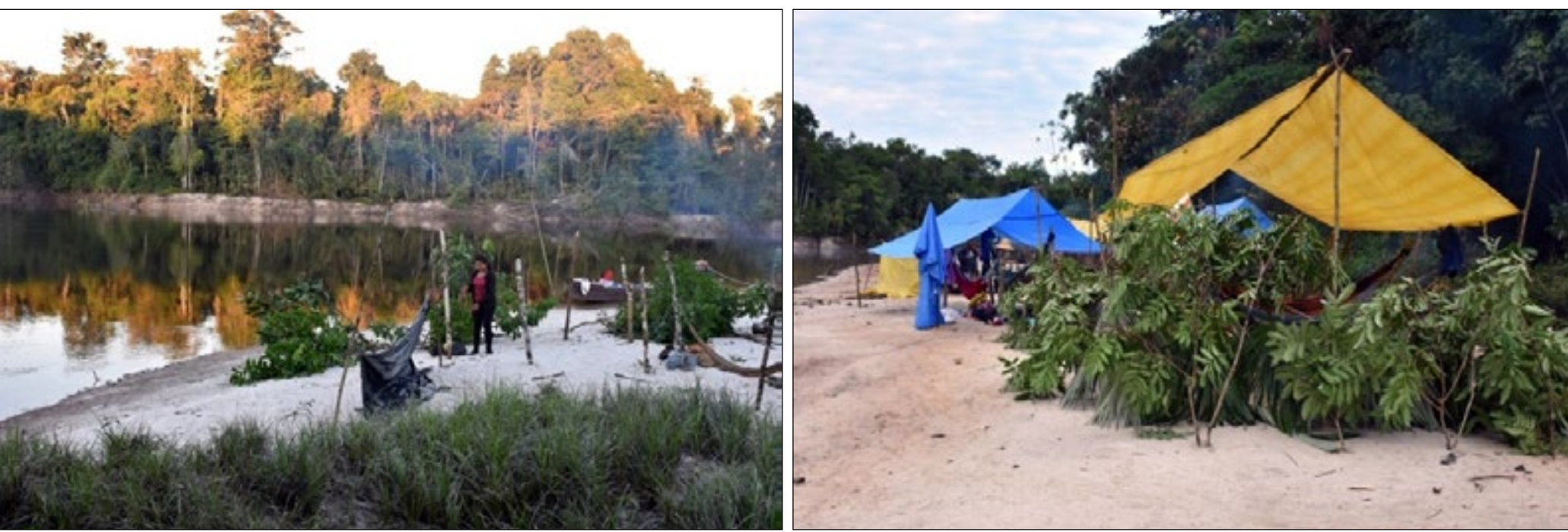

Figura 15 - Barreiras físicas, compostas por galhos e lonas plásticas, instaladas ao redor das redes, em acampamento temporário em frente ao microterritório remanso. Foto: Myrian Barboza (2017). 
para os humanos e malcheirosos para não humanos". No caso Katukina, os fortes aromas dos óleos, breu e sabão atenuam o cheiro natural das/os indígenas de maneira a não serem percebidos pelos seres intangíveis e, assim, coexistirem neste território.

\section{CONSIDERAÇÕES FINAIS}

Embora grande parte dos estudos etnológicos sobre territorialidade indígena não reconheça a relevância e a função feminina indígena, oferecemos vários exemplos, considerando diferentes escalas e interações, de que a territorialidade Katukina ocorre em termos de gênero e corporalidade. Homens e mulheres Katukina são coparticipantes e possuem papéis complementares no processo de territorialização. Todavia, as mulheres constituem o principal alvo dos seres intangíveis e, além disso, elas e seus corpos imprimem marcas importantes no território, reforçando a singularidade dos seus corpos.

No caso dos homens, os fluidos exclusivamente masculinos, como esperma, nunca foram apontados como elemento "perigoso", com capacidade de transferência odorífica para as mulheres ou susceptível à limpeza cuidadosa, para que seu odor não seja sentido e descoberto pelos seres intangíveis. Assim, este forte contraste entre fluidos de gênero - esperma masculino e sangue feminino (durante os períodos menstrual ou puerperal) -, no que concerne às suas representações e aos cuidados envolvidos para que sua exalação não seja evidenciada, indica que o movimento e a interação das/os Katukina com e no território são regulados principalmente pelos corpos e fluidos femininos. Assim, sugerimos o conceito de corpoterritorialização porque fluidos e corpos femininos estampam e direcionam o fluxo de territorialização Katukina, além de acompanharmos o importante debate arguido pelo território epistêmico feminino indígena.

As/Os Katukina possuem microterritórios específicos de uso e ocupação de acordo com o gênero: microterritórios femininos e microterritórios masculinos. Inclusive, o mesmo microterritório, como as praças onde ocorrem as danças ritualísticas, possuem espaços de ocupação opostos para cada gênero, por isso, os denominamos de microterritórios antagônicos. De maneira geral, os microterritórios masculinos são declaradamente reconhecidos e explicitamente proibitivos para as mulheres, principalmente durante os rituais. Todavia, encontramos microterritórios femininos aparentemente ocultos, porém existentes. Os microterritórios femininos são constituídos por espaços de acesso às roças, como trilhas na mata ou antigas capoeiras. As/Os Katukina não relataram e nem observamos casos de microterritórios homoafetivos e transafetivos.

As/Os Katukina possuem uma intrincada relação com o território e seus constituintes, que inclui assinaturas sensoriais da corpoterritorialização. 
Estas assinaturas podem funcionar como placas, marcas territoriais físicas de coexistência, como a exibição e delimitação de uso de territórios entre as/ os Katukina de diferentes aldeias. Estas assinaturas constituem, então, uma maneira de dar visibilidade à presença e ao uso de determinados microterritórios e, algumas vezes, podem funcionar como convites de visitas para interação entre grupos de diferentes aldeias. Todavia, existem assinaturas territoriais que atuam de maneira contrária, auxiliando na invisibilidade física e/ou olfativa das/os Katukina. Assim, através de medidas sensoriais protetoras, as/os Katukina tentam dificultar sua percepção perante os seres intangíveis. As medidas físicas utilizadas funcionam como barreiras, constituídas por galhos de árvores, lonas industrializadas e os nossos próprios corpos acomodados nas redes.

As/Os Katukina estão constantemente conscientes sobre o perigo dos aromas corporais (sangue humano e animal, suor humano, entre outros) e vegetais (plantas tóxicas), que facilitam sua percepção pelos seres intangíveis. Assim, elas/es reconhecem os benefícios de fragrâncias fortes, seja de produtos naturais (óleo vegetal e breu) ou industrializados (sabão em pó) na compilação de estratégias protetoras. Estes perfumes funcionam como neutralizadores do cheiro natural dos fluidos corporais Katukina, principalmente o sangue menstrual e puerperal, que possuem grande poder de exalação e percepção. $\mathrm{O}$ uso destes produtos com forte potencial aromático consiste em uma maneira de atenuar a presença dos corpos Katukina nos microterritórios, e assim não serem capturados. Dessa maneira, as assinaturas sensoriais de corpoterritorialização Katukina, sejam elas físicas ou olfativas, utilizam produtos da floresta, industrializados, e até mesmo corpos de agentes externos, como foram os nossos próprios corpos.

Devido à capacidade de transmissão do "cheiro" feminino, além do poder de alcance e da percepção pelos seres intangíveis, as/os Katukina devem respeitar o conjunto de normas restritivas. As restrições estão relacionadas às condições específicas da mulher de liberação de odores fortes, como menstruação e puerpério. Mesmo que as circunstâncias biológicas sejam femininas, tanto o homem quanto a mulher, além dos recémnascidos, devem cumprir as regras, sendo que o período restritivo é mais longo para as mulheres.

Nosso estudo demonstra que os corpos e gênero Katukina se incorporam fortemente nas relações com e entre o território e seus constituintes. Nesta interação, os corpos femininos possuem papel primordial na regulação dos movimentos, diários e anuais, individuais, da família e de toda a aldeia. Reforçamos, ainda, que as/os Katukina constroem e reconstroem ativamente seus mundos sociais e físicos conceitualizados em termos de gênero e corporalidade, embora sejam influenciados por 
diferentes marcadores, incluindo espiritualidade, parentesco, mobilidade, dieta, entre outros.

Por fim, aclamamos a importância e a necessidade urgente da compreensão e do uso do território epistêmico feminino indígena como premissa elucidativa das nossas indagações quanto às territorializações indígenas em um triste cenário geral de sua invisibilidade acadêmica. Somente por meio de uma maior sensibilidade e credibilidade para as/os intelectuais indígenas, negras/os, quilombolas, e demais grupos sociais categorizados como "tradicionais" e aqueles considerados da "periferia", além do exercício de compreensão da conexão corpo-território indígena (Correa Xakriabá 2018), poderemos permitir "novos equívocos criativos" (Azevedo 2016) e evitar o epistemicídio desses valorosos corpos-epistêmicos (L. Alves 2019a).

\section{AGRADECIMENTOS}

Agradecemos, em especial, às/aos Katukina, pelas experiências e aprendizados compartilhados. Agradecemos à professora Marianne Schmink, pela revisão final deste artigo, assim como pelas sugestões prévias dos professores Richard Kernaghan e Augusto Oyuela-Caycedo; à revisão do resumen por Florencia Lathrop Rossi e Grace Palacios Chávez; e aos comentários dos revisores e das organizadoras deste dossiê. Forte agradecimento à equipe do Núcleo de Pesquisas e Documentação das Expressões Afro- brasileiras e Caribe (NPDAFRO/UFOPA) e a todas/ os alunas/os negras/os, quilombolas e indígenas da UFOPA, pelos estímulos e debates sobre os territórios epistêmicos. Axé!

As nossas idas a campo foram possíveis em função dos prêmios obtidos por Myrian Barboza, na Universidade da Florida, como Vivian G. Nolan Graduate Fellowship (Latin American Studies/UF, 2015), James C. Waggoner Fr. Grant-in-Aid Awards (Anthropology program/UF, 2015), O. Ruth McQuown Award (College of Liberal Arts and Science/UF, 2016), Polly and Paul Doughty Research Awards (Anthropology program/UF, 2016), Graduate School Doctoral Research Travel Award (Graduate School/UF, 2017) e fohn M. Goggin Award (Anthropology program/UF, 2017).

Myrian Barboza foi bolsista do programa de Doutorado Pleno no Exterior da Coordenação de Aperfeiçoamento de Pessoal de Ensino Superior (CAPES, Brasil, 2014-2018), do Elizabeth Eddy Doctoral Completion (Anthropology program/UF, 2018) e do TCD Tuition support award (Tropical, Conservation and Development program/UF, 2018). Agradecemos à ONG OPAN (Operação Amazônia Nativa), pelo apoio logístico e por todo suporte, aos Conselhos de Povos Indígenas de Jutaí (COPIJU), à Associação dos Professores Indígenas de Jutaí (APIJU) e ao Núcleo de Educação Escolar Indígena (NEEI) da prefeitura de Foz de Jutaí, por todo apoio para realização de nossas atividades. 


\section{REFERÊNCIAS}

Almeida, R. 2009. Expedição da FUNAI inicia entrada na selva, in Povos Indígenas no Brasil. ISA. Disponível em: https://pib.socioambiental.org/pt/Not\%C3\%ADcias?id=79017. Acesso em: jul. 2019.

Alves, L. C. 2019a. Reivindicando o território epistêmico: mulheres negras, indígenas e quilombolas interpelando a antropologia. Revista Humanidades e Inovação 6(16):82-94

Alves, L. C. 2019b. Mulheres indígenas na pós-graduação: trajetórias e rexistências. Dissertação de Mestrado, Departamento de Antropologia, Universidade de Brasília, Brasília.

Alves, M. 1998[2002]. Iris do arco-íris desumano. Cadernos Negros 21(25):30.

Azevedo, D. L. 2016. Forma e conteúdo do Bahsese Yepamahsâ (Tukano). Fragmentos do espaço Di’tal Nhk (terra/floresta). Dissertação de Mestrado, Universidade Federal do Amazonas, Departamento de Antropologia Social, Manaus.

Baniwa, B. 2018. Mulheres e território: reflexão sobre o que afeta a vida das mulheres indígenas quando os direitos territoriais são ameaçados. Vukápanavo: Revista Terena 1(1):165-170.

Barboza, M. S. L., F. A. G. Andrade, e R. S. L. Barboza. 2011. Quando come morcego baradakon fica forte: o consumo de morcegos (CHIROPTERA, Mammalia) pelos indígenas Katukina do Rio Biá na Amazônia (AM), in Reflexões indigenistas. Editado por R. S. V. Arruda, A. Jakubaszko, e M. M. Ramires, pp. 45-60. Campinas: Curtnimuendaju.

Barboza, M. S. L. 2019. “Tükuna cosmopolitical cartography”: the gendered meaning and use of territories by Katukina indigenous people (Biá River, Brazilian Amazonia). Tese de Doutorado, University of Florida, Departamento de Antropologia, Gainesville.

Barreto, J. R. R. 2012. Formação e transformação de coletivos indígenas do noroeste amazônico: do 
mito à sociologia das comunidades. Dissertação de Mestrado, Universidade Federal do Amazonas, Departamento de Antropologia Social, Manaus.

Barreto, J. P. L. 2013. Wai-Mahsã: peixes e humanos. um ensaio de antropologia indígena. Dissertação de Mestrado, Universidade Federal do Amazonas, Departamento de Antropologia Social, Manaus.

Barreto, J. P. L., e G. Mendes dos Santos. 2017. A volta da cobra canoa: em busca de uma antropologia indígena. Revista de Antropologia 60(1):84-98. DOI: https://doi.org/10.11606/2179-0892.ra.2017.132068.

Barreto, J. P. L. 2018. Waimahsã: peixes e humanos. Manaus: EDUA.

Belaunde, L. E. 2001. Viviendo bien: género y fertilidad entre los Airo-Pai de la Amazonía peruana. Lima, Perú: Centro Amazónico de Antropología y Aplicación Práctica.

Belaunde, L. E. 2006. A força dos pensamentos, o fedor do sangue: hematologia e gênero na Amazônia. Revista de Antropologia 49(1):205-243. DOI: http://dx.doi.org/10.1590/S0034-77012006000100007.

Benites, S. 2018. Viver na língua Guarani Nhandeva (mulher falando). Dissertação de Mestrado, Museu Nacional/Universidade Federal do Rio de Janeiro, Departamento de Antropologia Social, Rio de Janeiro.

Cabnal, L. 2010. Acercamiento a la construcción de la propuesta de pensamiento epistémico de las mujeres indígenas feministas de Abya Ayla, in Feminismos diversos: el feminismo comunitario, pp. 11-15. Madrid: Acsur las Segovuas.

Cabnal, L. 2012. Documento en construcción para aportar a las reflexiones continentales desde el feminismo comunitario, al paradigma ancestral originario del "Sumak Kawsay" - Buen Vivir. Disponível em: https://amismaxaj.files.wordpress.com/2012/09/buen-vivir-desde-el-feminismo-comunitario.pdf. Acesso em: nov. 2019. 
Cabnal, L. 2015. Without being consulted: the commodification of our body-land territory, in women defending the territory: experiences of participation in Latin America. Editado por L. M. Carvajal, L. Cabnal, G. Ruales, Á. Cuenca, C. Aliaga \& S. Gatica. pp. 41-56. Colombia: Fundación Cultural de Artes Gráficas.

Carneiro, A. S. 2005. A construção do outro como não-ser como fundamento do ser. Tese de Doutorado, Universidade de São Paulo, Departamento de Educação, São Paulo.

Correa Xakriabá, C. N. 2018. O barro, o genipapo e o giz no fazer epistemológico de autoria Xakriabá: reativação da memória por uma educação territorializada. Dissertação de Mestrado, Universidade de Brasília, Departamento de Sustentabilidade junto a Povos e Terras Tradicionais, Brasília.

Costa, L. 2007. As faces do jaguar. Parentesco, história e mitologia entre os Kanamari da Amazônia Ocidental. Tese de Doutorado, Museu Nacional/Universidade Federal do Rio de Janeiro, Departamento de Antropologia Social, Rio de Janeiro.

Deleuze, G., e F. Guattari. 1987. Of the refrain, in A thousand plateaus: capitalism and schizophrenia. Editado por G. Deleuze, e F. Guattari, pp. 310-350. Minneapolis: University of Minnesota Press.

Descola, P. 1996. Constructing natures: symbolic ecology and social practice. In Nature and society: anthropological perspectives. Editado por Philippe Descola, e G. Pálsson, pp. 82-102. London/New York: Routledge.

Descola, P. 2001. The genres of gender: local models and global paradigms, in Gender in Amazonia and Melanesia: an exploration of the comparative method. Editado por T. Gregor, e D. Tuzin, pp. 91-114. Berkeley: University of California Press.

Deturche, J. 2009. Les Katukina du Rio Biá (Etat d’Amazonas - Brésil): histoire, organization sociale et cosmologie. $\mathrm{PhD}$ dissertation, University of Paris Ouest Nanterre, Paris. 
Deturche, J. 2012. Narrativas e história do contato Katukina: 'Etno-história' de um povo da Amazônia brasileira. Antropologia em Primeira Mão 131:5-15.

Deturche, J., e K. Hoffmann. 2016. Nomes, subgrupos e qualidades totêmicas? Nas águas de uma sociologia Katukina (rio Biá, sudoeste amazônico). Ilha - Revista de Antropologia 18:99-120.

Dorronsoro, B. 2013. El território cuerpo-tierra como espacio-tempo de resistências y luchas en las mujeres indigenas y originarias. IV Coloquio Internacional de Doutorandos/as do CES.

Espinosa Miñoso, Y. 2014. Introducción y presentación, in Tejiendo de otro modo: feminismo, epistemología y apuestas descoloniales en Abya Yala. Editado por Y. Espinosa Miñoso, D. G. Correal e K. O. Muñoz, pp. 13-52. Popayán: Editorial Universidad del Cauca.

Evaristo, C. 2007. Da grafia-desenho de minha mãe, um dos lugares de nascimento de minha escrita, in Representações performáticas brasileiras: teorias, práticas e suas interfaces. Organizado por M. A. Alexandre, pp. 16-21. Belo Horizonte: Mazza.

Fausto, C. 2008. Donos demais: maestria e domínio na Amazônia. Mana 14(2):329-366. DOI: http:// dx.doi.org/10.1590/S0104-93132008000200003.

Fisher, M. 2018. Anthropology in the meantime: experimental ethnography, theory, and method for the twenty-first century. Durham: Duke University Press.

Graúna, G. 1999. Cartografia do imaginário, in Canto mestizo, pp. 69. Maricá/RJ: Bloocs Editora.

Hernández, D. T. C. 2016. Una mirada muy otra a los territorios-cuerpos femeninos. A very other gaze at the territories-female bodies. Solar 12(1):46.

Krahô, C. P. 2017. Wato ne hômpu ne kãmpa convivo, vejo e ouço a vida Mehi (Mãkrarè). Dissertação 
de Mestrado, Universidade de Brasília, Departamento de Desenvolvimento Sustentável, Brasília.

Lasmar, C. 1996. Antropologia feminista e etnologia amazônica: a questão do gênero nas décadas de 70 e 80. Dissertação de Mestrado, Museu Nacional/Universidade Federal do Rio de Janeiro, Departamento de Antropologia Social, Rio de Janeiro.

Lasmar, C. 1999. Mulheres indígenas: representações. Estudos Feministas 7(1-2):143-156.

Lasmar, C. 2005. De volta ao lago de leite: gênero e transformação no Alto Rio Negro. São Paulo: Editora UNESP/ISA; Rio de Janeiro: NUTI.

Lévi-Strauss, C. 1943. Guerre et commerce chez les indiens de l'Amérique du Sud. Renaissance 1(2):122-139.

Lubel, A. F., e N. Soares-Pinto. 2017. Apresentação ao dossiê: dossiê antropologias das T/terras. As T/ terras e suas potencias etnográficas. Revista de @ntropologia da UFSCAR 9(1):7-13.

Maia, G. S. 2016. Bahsamori: o tempo, as estações e as etiquetas sociais dos Yepamahsã (Tukano). Dissertação de Mestrado, Universidade Federal do Amazonas, Departamento de Antropologia Social, Manaus.

Maizza, F. 2017. De mulheres e outras ficções: contrapontos em antropologia e feminismo. Ilha 19(1):103-135.

Marcus, G. E. 1998. Ethnography through thick \& thin. New Jersey: Princeton University Press.

McCallum, C. 1999. Aquisição de gênero e habilidades produtivas: o caso Kaxinawá. Revista Estudos Feministas 7(1-2):157-175.

McCallum, C. 2001. Gender and sociality in Amazonia: how real people are made. Oxford/New York: Berg Press. 
Michaelis. Dicionário Brasileiro da Língua Portuguesa. 2019. Remanso. Disponível em: http://michaelis. uol.com.br/busca?id=w4XAL. Accesso em: 15 ago. 2019.

Paredes, J. 2011. Hilando fino, desde el feminismo comunitario. La Paz: Comunidad Mujeres Creando Comunidad.

Paredes, J. 2017. El feminismocomunitario: la creación de un pensamiento propio. Corpus 7(1):1-9. DOI: http://dx.doi.org/10.4000/corpusarchivos.1835.

Prates, L. 2018. Meu corpo é meu lugar de fala, in Um corpo negro, pp. 63. São Paulo: Nosotros Editorial.

Rea, C., C. G. Paradis, e I. A. S. Amansio. 2018. Traduzindo a África queer. Salvador: Editora Devires.

Rival, L. 1998. Androgynous parents and guest children: the Huaorani couvade (Curl Essay Prize). Fournal of the Royal Anthropological Institute 5(4):619-642. DOI: http://dx.doi.org/10.2307/3034825.

Rylands, A. B. 1982. The behaviour and ecology of three species of marmosets and tamarins (Callitrichidae, Primates) in Brazil. Doctoral thesis, University of Cambridge, London.

Santos, B. S. 2007. Para além do pensamento abissal: das linhas globais a uma ecologia de saberes. Novos Estudos CEBRAP (79):71-94.

Segato, R. L. 1998. Os percursos do gênero na antropologia e para além dela. Série Antropologia (236):1-22.

Silva, M. 2018. Comentários à dissertação de João Paulo Lima Barreto, "Wai-Mahsã, peixes e humanos: um ensaio de antropologia indígena”. Cadernos do NEAI 1(2).

Soares-Pinto, N. 2017. De coexistências: sobre a constituição de lugares Djeoromitxi. Revista de @ ntropologia da UFSCar 9(1):61-82. 
Sugawara, K. 1988. Visiting relations and social interactions between residential groups of the Central Kalahari San: Hunter-gatherer camp as a micro-territory. African Study Monographs 8(4):173-211.

Tupinambá, N. [Silva, N. B.]. 2017. Identidades, vozes e presenças indígenas na Universidade de Brasília sob a ótica da análise de discurso crítica. Dissertação de Mestrado, Universidade de Brasília, Departamento de Linguística, Brasília.

Viveiros de Castro, E. 1998. Cosmological deixis and amerindian perspectivism. fournal of the Royal Anthropological Institute 4(3):469-488. DOI: http://dx.doi.org/10.2307/3034157.

Wolff, C. S. 1998. Mulheres da floresta: uma história do Alto furuá - Acre (1890- 1945). São Paulo: HUCITEC. 